\title{
A new giant basal titanosaur sauropod in the Upper Cretaceous (Coniacian) of the Neuquén Basin, Argentina
}

\author{
Leonardo S. Filippi ${ }^{\text {a, * }}$, Leonardo Salgado b, c, Alberto C. Garrido d, e \\ ${ }^{a}$ Museo Municipal Argentino Urquiza, Jujuy y Chaco s/n, 8319 Rincón de los Sauces, Neuquén, Argentina \\ ${ }^{\mathrm{b}}$ CONICET, Argentina \\ c Instituto de Investigación en Paleobiología y Geología, Universidad Nacional de Río Negro-Conicet, Av. Gral. J. A. Roca 1242, 8332 General Roca, Río Negro, \\ Argentina \\ dMuseo Provincial de Ciencias Naturales “Profesor Dr. Juan A. Olsacher”, Dirección Provincial de Minería, Etcheluz y Ejército Argentino, 8340 Zapala, \\ Neuquén, Argentina \\ e Departamento Geología y Petróleo, Facultad de Ingeniería, Universidad Nacional del Comahue, Buenos Aires 1400, Neuquén 8300, provincia del Neuquén, \\ Argentina
}

\section{A R T I C L E I N F O}

\section{Article history:}

Received 21 November 2018

Received in revised form

3 February 2019

Accepted in revised form 9 March 2019

Available online 28 March 2019

\section{Keywords:}

Sauropoda

Titanosauria

Upper Cretaceous

Neuquén Group

Sierra Barrosa Formation

Patagonia

\begin{abstract}
A B S T R A C T
A new basal sauropod titanosaur, Kaijutitan maui gen. et sp. nov., is described. The holotype of this species, which comes from the Sierra Barrosa Formation (upper Coniacian, Upper Cretaceous), consists of cranial, axial, and appendicular elements presenting an unique combination of plesiomorphic and apomorphic characters. The most notable characteristic observed in Kaijutitan is the presence of anterior cervical vertebrae with bifid neural spines, a condition that would have evolved several times among sauropods. The phylogenetic analysis places Kaijutitan as a basal titanosaur, the sister taxon of Epachthosaurus + Eutitanosauria. The new species supports the coexistence, in the Late Cretaceous (Turonian-Santonian), of basal titanosaurs and eutitanosaurian sauropods, at least in Patagonia.
\end{abstract}

(c) 2019 Elsevier Ltd. All rights reserved.

\section{Introduction}

Sauropods are among the most abundant non-avian dinosaurs in the fossil record. These quadrupedal megaherbivores include the largest terrestrial animals that have ever existed on the planet (Wilson, 2002; Wilson and Curry Rogers, 2005; Barrett et al., 2010; Sander et al., 2011), with truly gigantic forms, such as the basal titanosauriforms Brachiosaurus altithorax Riggs (1903), Giraffatitan brancai Janensch (1914) and Ruyangosaurus giganteus Lu et al. (2009), and the titanosaurs Argentinosaurus huinculensis Bonaparte and Coria (1993), Puertasaurus reuili Novas et al. (2005), Futalognkosaurus dukei Calvo et al. (2007a,b), Dreadnoghutus schrani Lacovara et al. (2014), Notocolossus gonzalezparejasi González Riga et al. (2016) and Patagotitan mayorum Carballido et al. (2017). Their remains have been found on all continents,

\footnotetext{
* Corresponding author.

E-mail address: Isfilippi@gmail.com (L.S. Filippi).
}

including Antarctica (Cerda et al., 2012). Sauropods, defined as the most inclusive clade that includes Saltasaurus loricatus but not Melanorosaurus readi (Yates, 2007) would have originated in the Late Triassic and predominated up to end of the Cretaceous (Upchurch et al., 2004); however, only titanosaurs survived until the end of the Cretaceous. This group of sauropods reached its greatest diversity in Gondwana, especially in South America (Bonaparte, 1986; Powell, 2003).

Late Cretaceous continental deposits in the area of Rincon de los Sauces (Neuquén, Argentina) have yielded, in the last fifteen years, numerous and important findings of titanosaurian sauropods (Calvo and González Riga, 2003; Calvo et al., 2007b; Coria et al., 2013; Filippi and Garrido, 2008; Filippi et al., 2011a,b; 2013; González Riga, 2003, 2005). Here, we present a new basal, giant titanosaur, which is the first basal titanosaur described for the Coniacian (Upper Cretaceous) of North Patagonia.

The holotypic material of the new species was found by a team of researchers from the Museo Municipal "Argentino Urquiza" and the Museo Provincial de Ciencias Naturales "Prof. Dr. Juan 
Olsacher". The new species, one of the few sauropods from the Sierra Barrosa Formation, preserves part of the skull, which is virtually unknown in large titanosaurs.

\section{Materials and methods}

\subsection{Anatomical abbreviations}

al, accessoy lamina, alp, anterolateral process; amp, anteromedial process, ap, acromion process; asp, ascending process; Bsph, basisphenoid, bpt, basipterygoid process; bt, basal tuber; ca, crista antotica; cap, capitulum; c, crest; cc, cranial cavity; cdl, centrodiapophyseal lamina; cf, coracoid foramen; cnc, cnemial crest; cpof, centropostzygapophyseal fossa; cprf; centroprezygapophyseal fossa; cr, cervical rib; cr.pro; crista prootica; cr. t, crista tuberalis; dp, diapophysis; dpc, deltopectoral crest; Eo, exoccipital, Eo-Op, exoccipital-opisthotic complex; ep, epipophyses; EPRL, epipophyseal-prezygapophyseal lamina; F, frontal; fh, femoral head; fo, foramen; ft, four trochanter; gc, glenoid cavity; ic, internal carotid; ICPOL, lateral centropostzygapophyseal lamina; ipof, infrapostzygapophyseal fossa; ir, interosseous ridge; lb, lateral bulge; Lsph, laterosphenoid; lpp, lateroposterior process; mdCPRL, medial division of the centroprezygapophyseal lamina; mf, metotic foramen; mt, medial tubercle; n, neurapophyses; nc, neural canal; ns, neural spine; oc, occipital condyle; of, oval fenestra; ol, olecranon; Orb; orbitosphenoid; P, parietal; pas, phalangeal articular surface; PCDL, posterior centrodiapophyseal lamina; PCPL, posterior centroparapophyseal lamina, plb, posterolateral bulge; pnf, pneumatic foramen, Po, postorbital; pocdf, postzygodiapophyseal fossa; PODL, postzygodiapophyseal lamina, pop, paraoccipital process; POSL, postspinal lamina; poz, postzygapophysis; pp, parapophysis; pped, pubic peduncle; prap, preacetabular process; prel, prezygoepipophyseal lamina; Pro, prootic; PRSL, prespinal lamina; prz, prezygapophysis; Ps, presphenoid; ptc, pituitary cavity; rac, radial condyle; scb, scapular blade; sdf, spinodiapophyseal fossa; spof, spinopostzygapophyseal fossa; sprf, spinoprezygapophyseal fossa; SPOL, spinopostzygapophyseal lamina; SPRL, spinoprezygapophyseal lamina; t, tuberosity; tp, transverse process; TPOL, intrapostzygapophyseal lamina; TPRL, intraprezygapophyseal lamina; ts, trochanteric shelf; tu, tuberculum; ulc, ulnar condyle; vf, ventral fossa; vk, ventral keel.

\subsection{Institutional abbreviations}

FWMSH, Fort Worth Museum of Science and History, Fort Worth, Texas, U.S.A.; MAU-Pv-CM, Museo Municipal Argentino Urquiza, Paleontología de Vertebrados, Cañadón Mistringa, Neuquén, Argentina; MGPIFD-GR, Museo de Geología y Paleontología del Instituto de Formación Docente Continua de General Roca, Río Negro; MML, Museo Municipal de Lamarque, Río Negro, Argentina; MPCA, Museo Provincial Carlos Ameghino, Cipolletti, Río Negro, Argentina; MUCPv, Museo Universidad Nacional del Comahue, Neuquén, Argentina; NMMNH, New Mexico Museum of Natural History and Science, Albuquerque, New Mexico, U.S.A.; SMA, Sauriermuseum Aathal, Aathal, Switzerland.

\section{Systematic paleontology}

Saurischia Seeley, 1888

Sauropoda Marsh, 1878

Titanosauriformes Salgado et al., 1997

Somphospondyli Wilson and Sereno, 1998

Titanosauria Bonaparte and Coria, 1993

Kaijutitan maui gen. et sp. nov.
Derivation of the name. From Kaiju, Japanese word that means "strange beast", usually translated into English as "monster", and titan, from the Greek "giant". The species name maui refers to the acronym of the Museo Municipal Argentino Urquiza, Rincon de los Sauces, Neuquén, Argentina.

Holotype. MAU-Pv-CM-522. (Figs. 2-10) Incomplete neurocranium MAU-Pv-CM-522/1 composed of supraoccipital, exoccipitals, left paraoccipital process, left exoccipital-opisthotic-prootic complex, left laterosphenoid and orbitosphenoid, basioccipitalbasiesphenoid complex; MAU-Pv-CM-522/2, anterior cervical vertebra; MAU-Pv-CM-522/9, incomplete posterior cervical vertebra; proximal fragment of cervical rib; MAU-Pv-CM-522/6, fragments from cervical ribs; MAU-Pv-CM-522/11, left second dorsal rib; MAU-PV-CM-522/8, incomplete dorsal rib; MAU-PV-CM$522 / 18$, fragment of dorsal rib; MAU-Pv-CM-522/35, anterior caudal vertebra; MAU-Pv-CM-522/17, left sternal plate; MAU-PvCM-522/19 incomplete left coracoid; MAU-Pv-CM-522/10, incomplete left scapula; MAU-Pv-CM-522/21, incomplete left humerus?; MAU-Pv-CM-522/34, right humerus; MAU-Pv-CM-522/12, left ulna; MAU-Pv-CM-522/30, incomplete right ulna; MAU-Pv-CM522/31, incomplete right radius?, MAU-Pv-CM-522/32, right metacarpal II; MAU-Pv-CM-522/33, right metacarpal III; MAU-PvCM-522/25, a fragment of ilium?; MAU-Pv-CM-522/29, incomplete right femur; MAU-Pv-CM-522/28, right tibia; MAU-Pv-CM522/13, left astragalus, MAU-Pv-CM-522/3, right distal epiphysis of metatarsal II; MAU-Pv-CM-522/5, and indeterminate remains. Diagnosis. Kaijutitan maui gen. et sp. nov. is characterized by the following autapomorphies (those indicated with the asterisks were recovered in the phylogenetic analysis) $(\mathbf{1})^{*}$ width between the basal tuberosities almost four times the width of the foramen magnum; (2) foramen for the internal carotid artery located posteriorly on the basipterygoid processes, almost at the middle of the distance between these processes and the basal tuberosities; (3) bifid neural spine in anterior cervical vertebrae; $(4)$ presence in the anterior cervical vertebrae of a medial tuber located posteriorly between both metapophyses; (5) spinopostzygapophyseal lamina (SPOL) in the anterior cervical, bifurcated in the spinal sector, generating anteroposteriorly elongated deep pneumatic cavities; (6) presence of a posteroventral keel in anterior cervical vertebrae, generated from the convergence of two ridges that originate from the posteroventral edge of the parapophysis; (7)* cervical vertebrae with an accessory lamina, which runs from the postzygodiapophyseal lamina (PODL) up to the spinoprezygapophyseal lamina (SPRL); (8)* absence of proximal pneumatopores in dorsal ribs; (9)* prespinal lamina triangular, product of a dorsal expansion in anterior caudal vertebrae; $(\mathbf{1 0})^{*}$ absence of a ventromedial process in the ventral margin of the scapula; (11)* tibial proximal condyle narrow, with its long axis anteroposteriorly oriented; (12)* tibial cnemial crest projecting anteriorly; and (13)* astragalus with foramina at base of ascending process.

Type Locality. Cañadón Mistringa (Fig. 1), about 9 km southwest of the city of Rincon de los Sauces, Pehuenches Department, northeastern Neuquén Province, Argentina.

Stratigraphic horizon. Sierra Barrosa Formation, Upper Cretaceous (upper Conician), Neuquén Group, Río Neuquén Subgroup, Neuquén Basin.

The specimen of Kaijutitan maui gen. et sp. nov. was disarticulated but its bones associated and distributed in an area of $20 \mathrm{~m}^{2}$.

The fossiliferous level is characterized by a monotonous succession of massive and reddish mudstones, in which thin horizons (less than $5 \mathrm{~cm}$ of thickness) alternate with greenish limestones and tabular sandy bodies (less than $12 \mathrm{~cm}$ of thickness) characterized by the presence of undulitic stratification, horizontal 


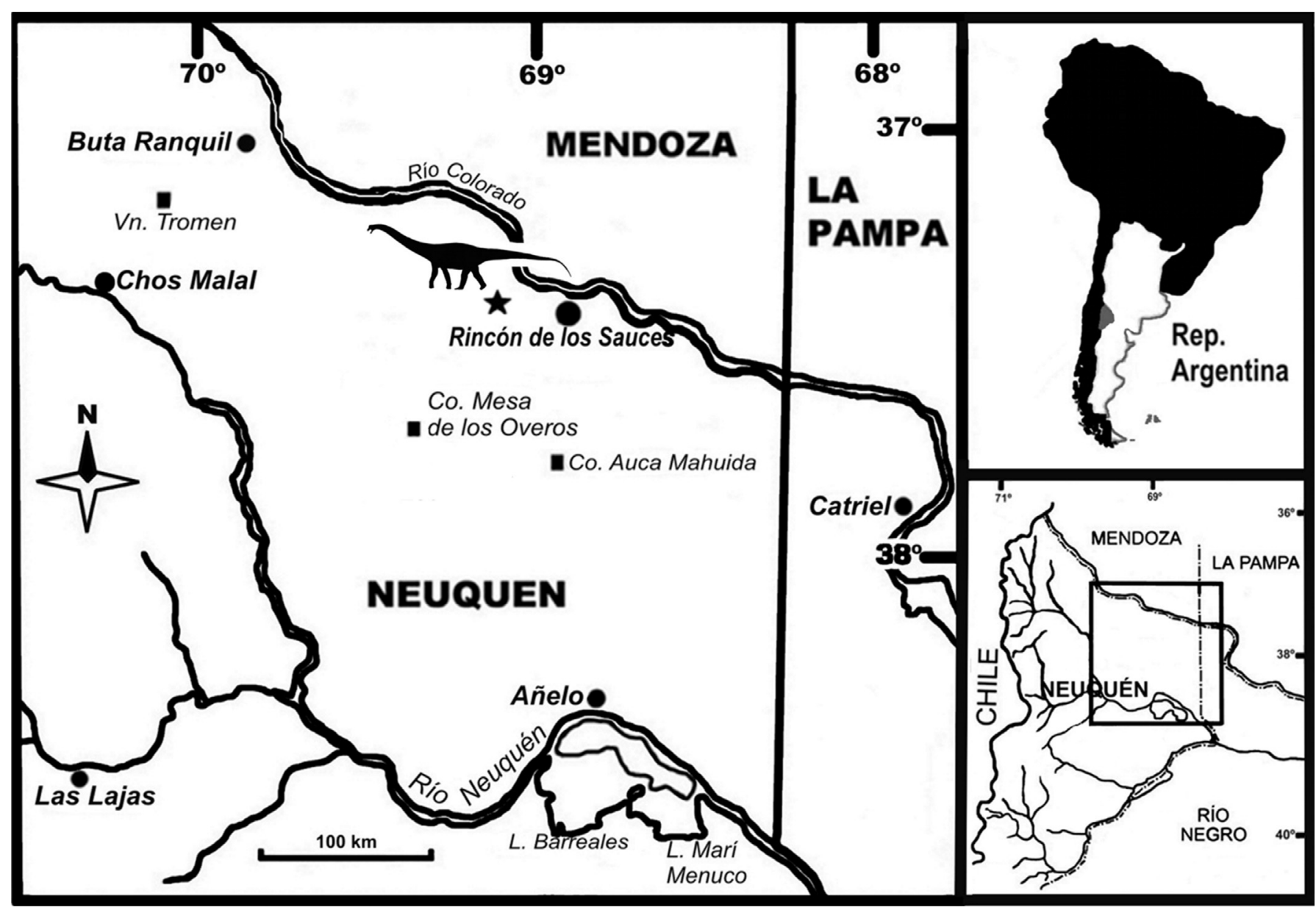

Fig. 1. Map showing the location of the Cañadón Mistringa site, star symbol indicates the procedence of the holotype of Kaijutitan maui gen. et sp. nov. MAU-Pv-CM-522.

stratification and/or low-angle cross-stratification, which are attributed to floodplain deposits.

\section{Description}

\subsection{Skull}

Cranial elements of this specimen include the complete neurocranium (MAU-Pv-CM-522/1) (Fig. 2), composed of the supraoccipital, exoccipital, left paraoccipital process, left exoccipitalopisthotic-prootic complex, left laterosphenoid and orbitosphoid, and basioccipital-basisphenoid complex. The impossibility of recognizing clear sutures between the different bony elements that make it up indicates an ontogenetic adult stage of the specimen.

\subsubsection{Supraoccipital}

The supraoccipital (Fig. 2A-B) is completely fused to the exoccipitals, forming, as in other sauropods, the posterodorsal margin of the skull and the dorsal margin of the foramen magnum. Although the borders of the foramen magnum are badly preserved, a subcircular contour is inferred, similar to that of the basal sauropod Shunosaurus lii (Chatterjee and Zheng, 2002), the basal macronarian Europasaurus (Marpmann et al., 2014; Fig. 13A) and the basal titanosauriform Giraffatitan brancai Paul, 1988 (Janensch, 1935, Fig. 2). Instead, in titanosaurs as Antarctosaurus (Huene, 1929); Saltasaurus (Bonaparte and Powell, 1980); Bonatitan (Martinelli and Foriasepi, 2004); Muyelensaurus (Calvo et al., 2007b); Pitekunsaurus
(Filippi and Garrido, 2008); Narambuenatitan (Filippi et al., 2011b); Rapetosaurus (Curry Rogers and Forster, 2004); Nemegtosaurus (Nowinski, 1971; Wilson, 2005); Vahiny (Curry Rogers and Wilson, 2014), the dorsoventral diameter is markedly larger than the transverse diameter. In Kaijutitan, as in Narambuenatitan, the height of the supraoccipital is slightly greater than the dorsoventral diameter of the foramen magnum (see Table SI2). In turn, in Saltasaurus (Powell, 1992, 2003) and Jainosaurus (Wilson et al., 2009), the height of the supraoccipital is twice the height of the foramen magnum. The supraoccipital protuberance, laterally limited by deep depressions, is lower and wider than in titanosaurs such as Bonatitan, Narambuenatitan, Sarmientosaurus (Martinez et al., 2016) and Tapuiasaurus (Zaher et al., 2011; Wilson et al., 2016), slightly surpassing the dorsal border of the exoccipitals. In Jainosaurus (Wilson et al., 2009), Phuwiangosaurus (Suteethorn et al., 2009) and the MML-194 specimen (García et al., 2008), the supraoccipital protuberance is relatively narrow and prominent. The supraoccipital lacks a midline ridge and a medial sulcus present in titanosaurs such as Quaesitosautus (Kurzanov and Bannikov, 1983), Saltasaurus, Rapetosaurus, Bonatitan, Muyelensaurus and the MML194 specimen (García et al., 2008).

\subsubsection{Exoccipital-opisthotic-prootic complex}

The prootic is completely fused with the exoccipital-opisthotic complex. A shallow prominence on the dorsolateral margin of the foramen magnum is observed as in the dicraeosaurid Amargasaurus cazaui (Salgado y Calvo, 1992), and other titanosaurian as 
A
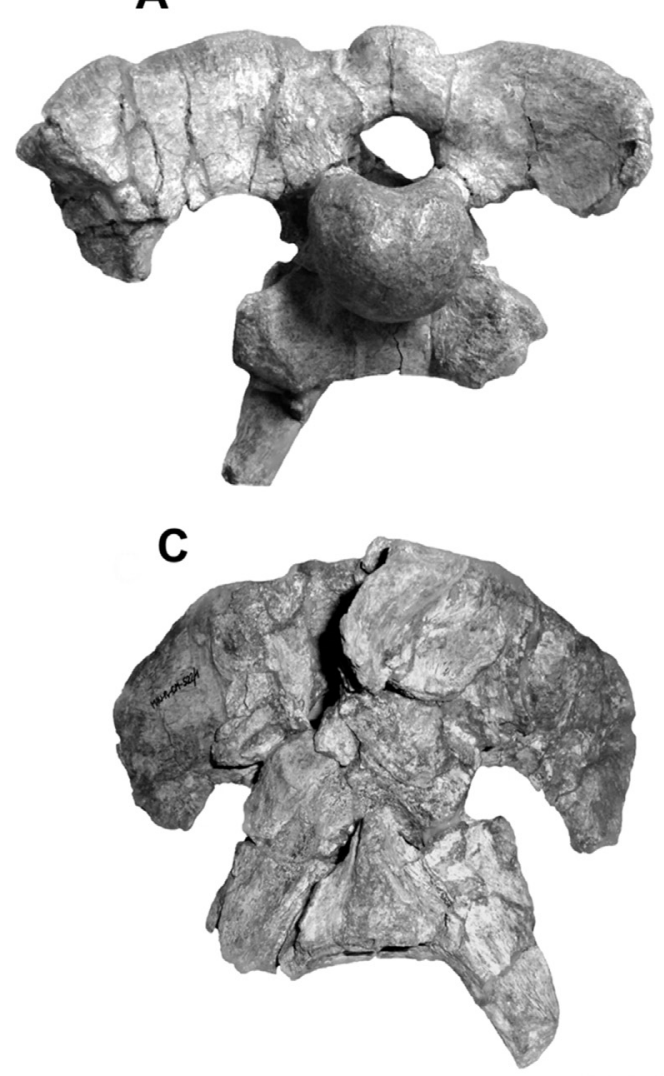

D

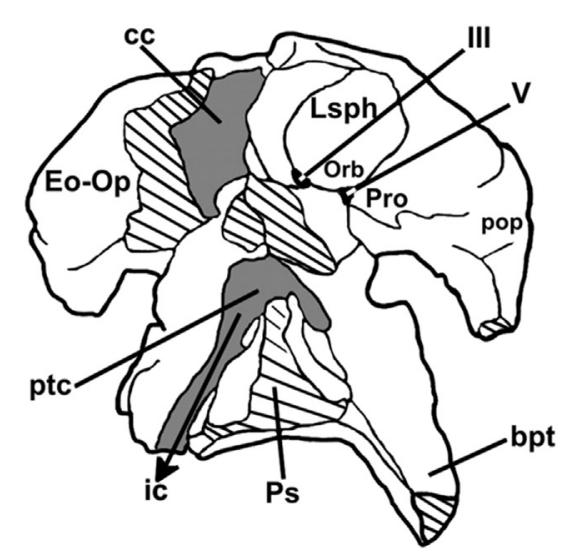

B

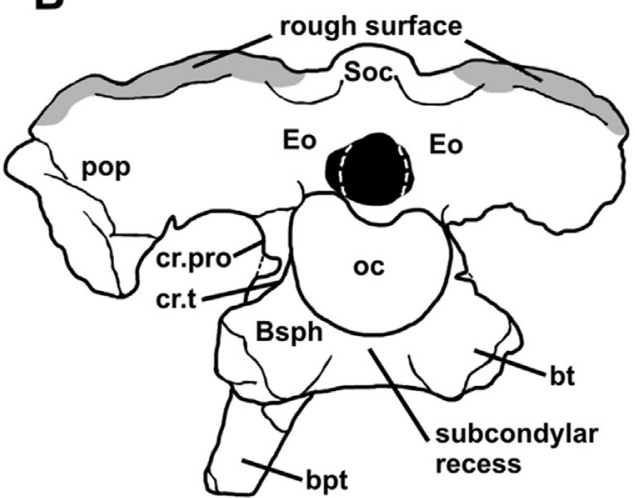

D

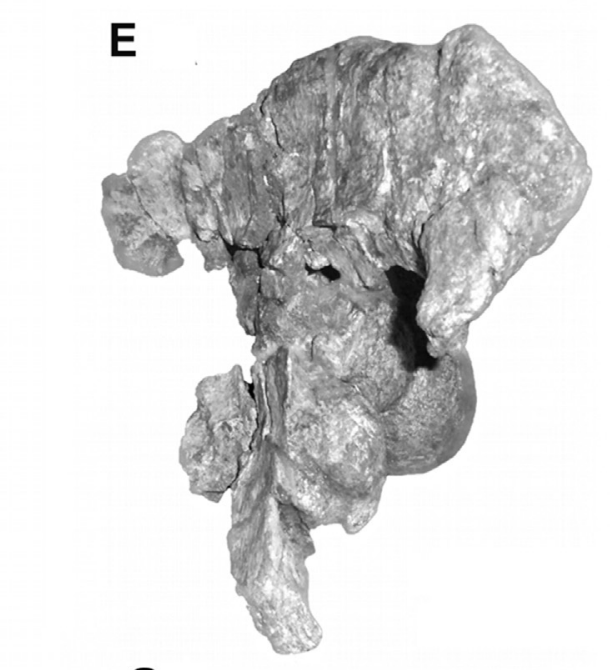

G

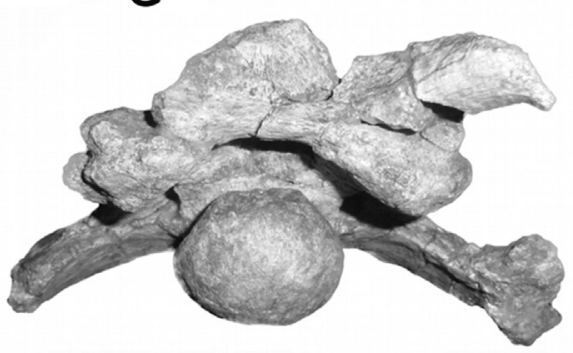

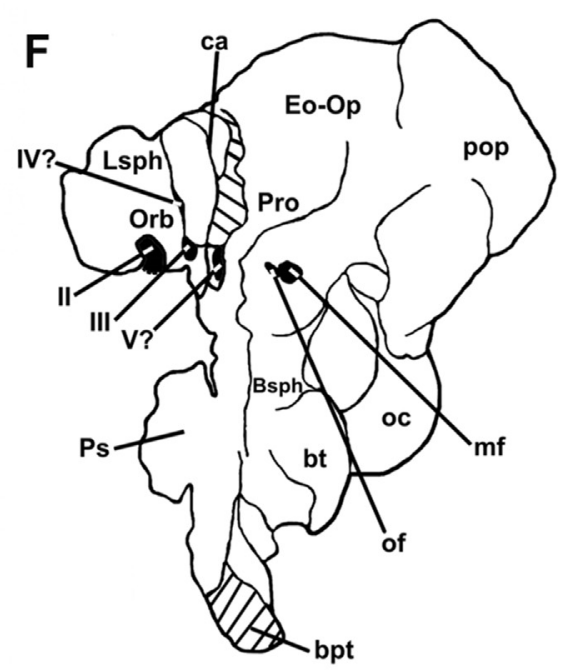

H

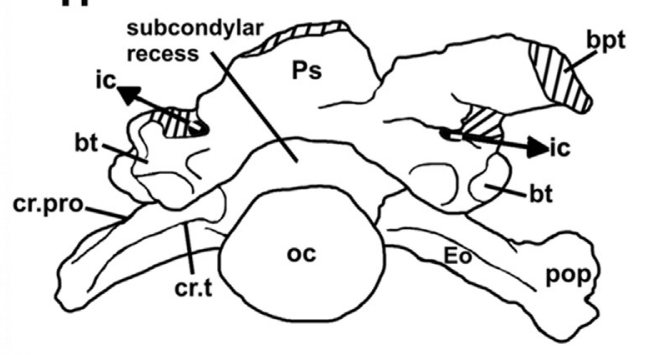

Fig. 2. Skull of Kaijutitan maui gen. et sp. nov. MAU-Pv-CM-522/1 (A-B), in posterior, (C-D), anterior, (E-F), lateral, (G-H), andventral views. Scale bar: $10 \mathrm{~cm}$. 
Quaesitosaurus, Nemegtosaurus, Saltasaurus, MUCPv-334 specimen (Calvo and Kellner, 2006) and MML-194 specimen (García et al., 2008). This structure was interpreted as a ligament insertion area probably related to the neck (Calvo and Kellener, 2006), while other authors interpreted it as an articular surface for the proatlas (Berman and Jain, 1982; Salgado and Calvo, 1992; Wilson et al., 2005). The rugose occipital condyle (Fig. 2A-B) is noticeably larger than the foramen magnum (see Table SI2), a condition present in the eusauropod Turiasaurus riodevensis (Royo-Torres and Upchruch, 2012; Fig. 3C and 5A), basal sauropods such as Shunosaurus lii (Chatterjee and Zheng, 2002; 5B) and titanosaurs such as Nemegtosaurus and Quaesitosaurus. In contrast, a similar proportion can be observed in titanosaurs such as Bonatitan, MUCPv-334 specimen (Calvo and Kellner, 2006, Fig. 1A), MGPIFD-GR-118 specimen (Paulina Carabajal and Salgado, 2007, Fig. 2D) and, to a lesser extent, in Antarctosaurus. Only the left paraoccipital process, incomplete distally, has been preserved; it is robust, wide and lateroventrally curved. Despite it is incomplete, the preserved morphology allows to infer the presence of the ventral nonarticular process that characterizes most titanosaurs. Anterior to the position where the exit of cranial nerve XII should be (this foramen is not preserved), the ventral edge of the paraoccipital process develops an acute ridge that corresponds to the ventral branch of the opisthotic. This ridge separates this last foramen from the metotic foramen, which is big and elliptical, being visible in lateral view, and corresponding to the exit of cranial nerves IX, X, XI, and the jugular vein (Chatterjee and Zheng, 2002, 2005). Anterior to the metotic foramen and separated by a thin wall of bone, there is the oval fenestra (Fig. 2E-F), as in the basal macronarian Europasaurus (Marpmann et al., 2014, Fig. 13B) and many titanosaurs (Powell, 2003; Martinelli and Forasiepi, 2004; Paulina Carabajal and Salgado, 2007; García et al., 2008). It is elliptical and has half of the size of the metotic foramen. On the contrary, in Saltasaurus the oval fenestra opens in the same duct than the metotic foramen (Powell, 2003). The crista prootica (Fig. 2 A-B), although not complete, is inferred to be very pronounced laterally, as observed in MUCPv-334 specimen (Calvo and Kellner, 2006, Fig. 3B), the MML194 specimen (García et al., 2008; Fig. 1B, D) and in Pitekunsaurus (Filippi and Garrido, 2008; Fig. 3.3). The foramen for the exit of nerve VII is not observable. The poor preservation in the sector between the prootic and the orbitosphenoid makes difficult to locate the exit foramen of nerve V. However, between the orbitosphenoid-laterosphenoid and the prootic, along a crack in the bones (Fig. 2E-F), there is observed a foramen delimited rostrally by the crista antotica and caudally by the crista prootica, which would correspond to the exit foramen of nerve $V$. All the branches of nerve $\mathrm{V}$ (ophthalmic, maxillary and mandibular) would come out through this single opening. The exit foramen of nerve $\mathrm{V}$ is bounded rostrally by the crista antotica, which separates it from the exit foramen of nerve III.

\subsubsection{Orbitosphenoid-laterosphenoid complex}

The left orbitosphenoid-laterosphenoid complex (Fig. 2E-F) articulates caudally with the exoccipital-opisthotic-prootic complex. The presphenoid-parasphenoid complex, which forms the cultriform process, has been partially preserved, allowing the pituitary fossa to be observed anteriorly. The crista antotica presents an anteroposteriorly compressed and posteriorly oriented morphology.The foramen exit of nerve III is located rostrally with respect to the crista antotica, being elliptical as in Bonatitan (Martinelli and Forasiepi, 2004, Fig. 7C), and different from the subcircular form present in the MML-194 specimen (García et al., 2008). Rostrally to the exit foramen of nerve III, there is the exit foramen of nerve II, which, although the ventral wall of bone is not preserved, would have been large and subcircular in shape. The foramen of nerve IV is not observable, although it could be included in a crack located on the foramen of nerve III. In Bonatitan, as in the specimen MML-194 (García et al., 2008), this foramen is located between the suture of the orbitosphenoid and the laterosphenoid at the bottom of a rostrocaudally extended fossa, being the smallest of all the foramina preserved (Martinelli and Forasiepi, 2004).

\subsubsection{Basioccipital-basiesphenoid complex}

This complex forms the floor of the braincase (Fig. 2) and is composed of the occipital condyle, the basal tuberosities, and the proximal portion of the left basipterygoid process. The cultriform process has not been preserved. The occipital condyle is subcircular, rugose, and has a prominent notch on its dorsal aspect, at the level of the ventral edge of the foramen magnum, which gives it a kidney-like appearance (Fig. 2A-B). The occipital condyle presents laterally on the neck, a fossa that does not extend towards the basal tuberosities, as in some sauropods (Tschopp et al., 2015; Character 80 ). If the supraoccipital is oriented vertically, which is considered the normal orientation (Salgado and Calvo, 1997), and if the foramen magnum is located on in the same plane, the occipital condyle inclines posteroventrally, as in most sauropods. As in the MML-194 specimen (García et al., 2008), the angle between the occipital condyle and such a plane is approximately $140^{\circ}$. In this orientation, based on the preserved proximal portion of the left element, the basipterygoid processes projected ventrally, unlike the MML-194 specimen (García et al., 2008), where they are projected rostroventrally. The proximal portion of left basipterygoid processes presents a subcircular shape in cross-section. Basal tuberosities in Kaijutitan are large both dorsoventrally and mediolaterally, and are clearly differentiated from the basipterygoid processes. The basal tuberosities of Kaijutitan are not bordered laterally. Ventrally they are bordered by a thick lip, as in Rapetosaurus (Curry Rogers and Forster, 2004), Pitekunsaurus, Narambuenatitan, Saltasaurus and MML-194 specimen, Antarctosaurus, Mongolosaurus (Mannion, 2010), Malawisaurus and Muyelensaurus. The posterior surface of the basal tuberosities are slightly concave, as in Giraffatitan, Phuwiangosaurus (Suteethorn et al., 2009), Malawisaurus (Gomani, 2005), Tapuiasaurus (Wilson et al., 2016), Pitekunsaurus and Narambuenatitan, and different from Camarasaurus and diplodocoids, where this surface is convex. The anteroposterior depth of basal tuberosities are nearly the half of the dorsoventral height, as in Brachiosaurus, Rapetosaurus and Lirainosaurus (Díez Díaz et al., 2011), different from Narambuenatitan, Pitekunsaurus, Muyelensaurus, Nemegtosaurus and Saltasaurus, which present sheet-like basal tuberosities, whose anteroposterior depth is nearly $20 \%$ of its dorsoventral height. The transverse width of basal tuberosities of Kaijutitan represents approximately half the diameter of the occipital condyle; they are very prominent and project laterally, as in Pitekunsaurus, although in the latter they are smaller and different from the basal tuberosities of Narambuenatitan (Filippi et al., 2011a,b; Fig. 3C) and Saltasaurus (Powell, 2003; Plate $19, A$ ), where they are reduced. The width of both basal tuberosities (Fig. 2A-B) is almost four times the width of the foramen magnum (see Table SI2), which doubles that of basal titanosauriforms such as Giraffatitan brancai (Janensch, 1935), Phuwiangosaurus sirindhornae (Suteethorn et al., 2009), and many titanosaurs as Pitekunsaurus, Muyelensaurus, Narambuenatitan, Bonatitan, Antarctosaurus, Sarmientosaurus, Mongolosaurus (Gilmor, 1933; Mannion, 2011), Saltasaurus, Malawisaurus (Jacobs et al., 1993; Gomani, 2005), Vahiny and Tapuiasaurus (Zaher et al., 2011; Wilson et al., 2016). Unlike Kaijutitan, in diplodocoid sauropods such as Diplodocus (Holland, 1906; Fig. 4) and Suuwassea emiliae (Harris and Dodson, 2004; Fig. 1C3), the tuberosities are very close to each other, being fused in the dicraeosaurid Amargasaurus cazaui (Salgado and Bonaparte, 1991, Fig. 1, Salgado and Calvo, 1992, Fig. 1B). However, the 

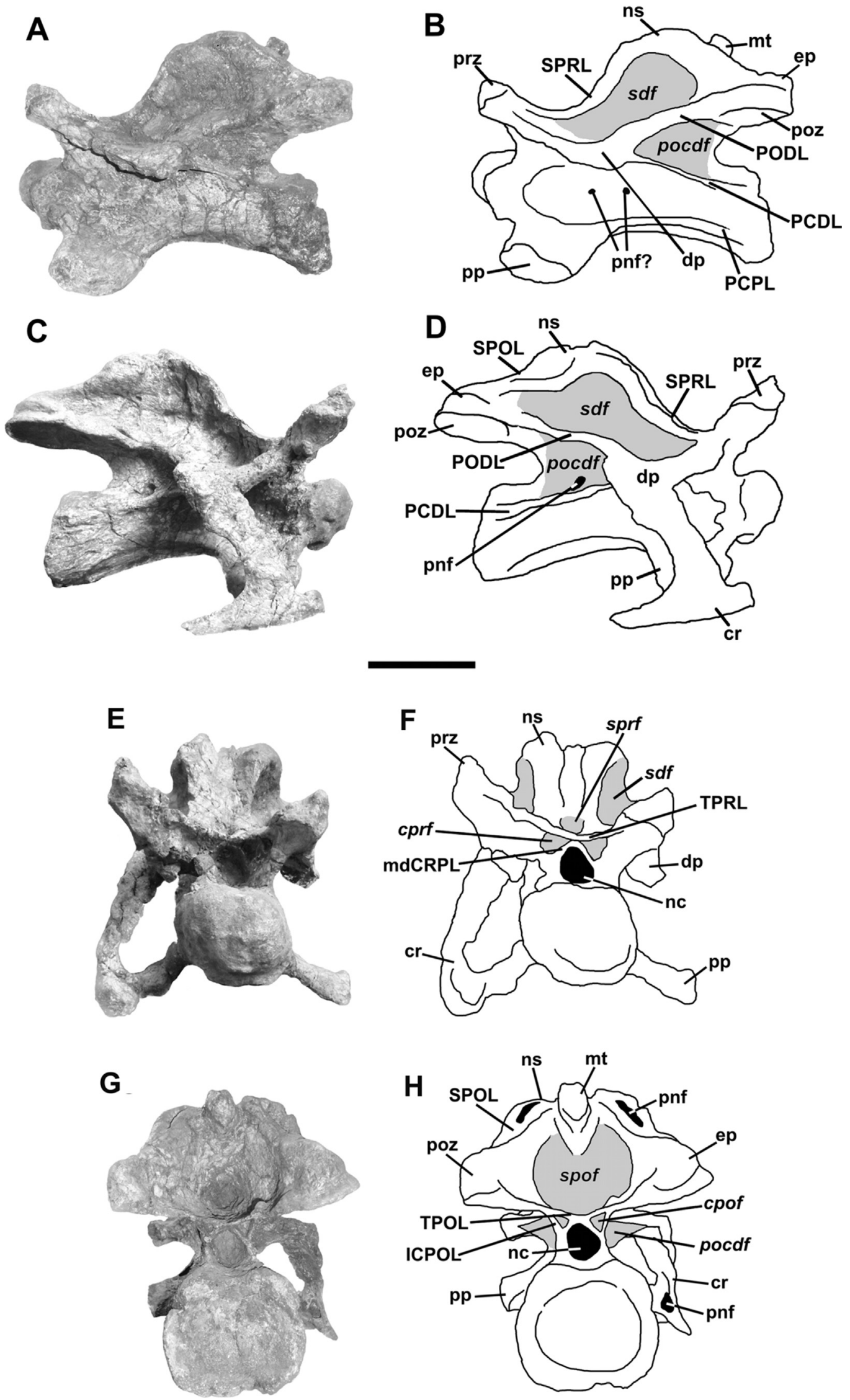

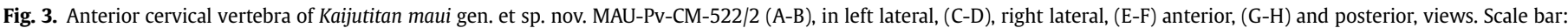
$10 \mathrm{~cm}$. 
ventral projection of the tuberosities is less pronounced than in most titanosaurs (e.g. Muyelensaurus, Pitekunsaurus, Antarctosaurus, Rapetosaurus, Sarmientosaurus, Tapuiasaurus). In Kaijutitan, the occipital condyle dorsoventral height/occipital condyle plus basal tuberosities dorsoventral height (Mannion et al., 2013, character 7) is 0.6, as in Nigersaurus and Apatosaurus, whereas in Europasaurus, Mongolosaurus, Giraffatitan and Phuwiangosaurus is greater than 0.6. This value for Kaijutitan may be interpreted as intermediate or even as a primitive state. Between the basal tuberosities, and below the occipital condyle, there is a basisphenoidal depression, similar to that present in Narambuenatitan (Filippi et al., 2011a,b; Fig. 3C). In Kaijutitan the basisphenoidal depression lacks a well-developed notch in the ventral midline, as is observed in Pitekunsaurus and, incipiently, in the MUCPv-334 specimen (Calvo and Kellner, 2006). The basal tuberosities lacks a foramina, present in Lirainosaurus (Díez Díaz et al., 2011; Fig. 3 and 4). The foramen for the internal carotid artery (Fig. 2C-D and G-H) is located posteriorly on the basipterygoid processes, almost at the middle of the distance between these processes and the basal tuberosities, differing from most titanosaurs, where it is located medially to these processes. In Jainosaurus (Wilson et al., 2011a), Lirainosaurus astibiae (Diez Díaz et al., 2011; Figs. 2 and 4) and Vahiny (Curry Rogers and Wilson, 2014; Fig. 3C, D), this foramen is located laterally to the basipterygoid processes, a primitive condition among non-titanosaurian sauropods (Paulina Carabajal, 2012; Curry Rogers and Wilson, 2014), such as Amargasaurus (Paulina Carabajal et al., 2014; Fig. 1B) and Phuwiangosaurus (Suteethorn et al., 2009; Fig. 9D). Because the presphenoid-parasphenoid complex is eroded and incomplete, it is possible to observe the pituitary fossa, partially exposed anteriorly, which is oval transversally and dorsoventrally compressed (Fig. 2C-D). The pituitary cavity is located as in the MML-194 specimen (García et al., 2008, Fig. 1C), anteriorly to the foramina of the internal carotids, which penetrate the cavity posteroventrally.

\subsection{Axial skeleton}

\subsubsection{Cervical vertebrae}

A complete and well-preserved anterior cervical vertebra (MAUPv-CM-522/2) (Figs. 3 and 4), probably the third one, was found near the neurocranium. Its centrum is opisthocoelous, elongated, with an elongation index lesser than 3.0 (see Table SI4), as in Alamosaurus (Gilmore, 1922, 1946; Lehman and Coulson, 2002), Europasaurus and Saltasaurus; and very compressed laterally, especially in the middle region. This laterally compressed is interpreted as natural. Ventrally, at the level of the parapophyses, which are located anteriorly, there is a pronounced concavity (Fig. 4C-D) that lacks the medial crest observed in Mongolosaurus (Mannion, 2011). In the probably dicraeosaurid Suuwassea (Harris, 2006, Fig. 5F), and in titanosaurs such as Pitekunsaurus, this ventral concavity extends practically along the entire length of the vertebral centrum. On the ventral side, two ridges develop from the posterior border of the parapophyses and converge posteriorly in a median keel, which reaches the posterior edge of the vertebral centrum (Fig. 4C-D). Although the anterior condyle is slightly deformed, it is oval, wider than high, and presents a groove or median notch on its dorsal border. The posterior cotyle lacks the notch, is quadrangular with a dorsal edge concave and a ventral plane flat. The lateral surface of the vertebral centrum is antereroposterioly concave, lacking true pleurocoel but having, mostly on the left side, two small pneumatic foramina. At both sides of the neural canal, there are the centroprezygapophyseal fossae (cprf). These are subtriangular and delimited by the medial division of the centroprezygapophyseal lamina (mdCPRL), the intraprezygapophyseal lamina (TPRL) and a robust centroprezygapophyseal lamina (CPRL). To both sides of the neural canal, there are the small and triangular postzygapophyseal fossae (cpof), delimited medially by the medial division of the centropostzygapophyseal lamina (mdCPOL), laterally by the lateral centropostzygapophyseal lamina (ICPOL) and dorsomedially by the intrapostzygapophyseal lamina (TPOL). In Erketu, the cprf and cpof are larger, presenting a well-developed TPOL (Ksepka and Norell, 2006), which is absent in the cervical C3 of Kaijutitan. Phuwiangosaurus (Suteethorn et al., 2009) presents the well-developed cprf, whereas the anterior cervicals of Saltasaurus present only the cpof (personal obs.). The diapophyses are located at the level of the roof of the neural canal, being slightly projected ventrally. The parapophyses are dorsoventrally flat and unexcavated. They project ventrally with a greater angle than the diapophyses (Fig. 3C-F), which results in the cervical rib hanging below the level of the centrum, as in Overosaurus paradasorum (Coria et al., 2013; Fig. 2), although to a lesser degree that in euhelopodids (D'Emic, 2012). The prezygapophyses are gracile compared with the robust postzygapophyses. The former processes project anterodorsally, and do not surpass the anterior border of the vertebral centrum, as in the anterior cervicals of other titanosaurs such as Futalognkosaurus (Calvo et al., 2007c), Pitekunsaurus (Filippi and Garrido, 2008), Rapetosaurus (Curry Rogers, 2009) and Saltasaurus (Powell, 1992, 2003). The presence of pre-epipophyses is not possible to confirm due to preservation. The prezygodiapophyseal lamina (PRDL) is well developed, as in the cervical vertebra 4 ? of Bonitasaura salgadoi (Gallina and Apesteguía, 2015) and in the anterior cervicals of Futalognkosaurus (Calvo et al., 2007c). Both prezygapophyses are connected by an TPRL that delimits dorsally the roof of the neural canal. Anteriorly, between the spinoprezygapophyseal lamina (SPRL) and the TPRL, there is a small, oval spinoprezygapophyseal fossa (sprf). The complete neural spine is relatively low and bifid (Fig. 3), consisting of two structures (metapophyses) that are anteroposteriorly elongated and posterolaterally expanded. The lateral surface of the neural spine is slightly concave anteroposteriorly. This concavity is part of the spinodiapofisial fossa. Other titanosauriforms present bifid cervical spines: Phuwiangosaurus, from the C7 (Suteethorn et al., 2009; Fig. 12), Euhelopus from the C12, and Huabeisaurus allocotus Pang and Cheng, 2000 (D'Emic et al., 2013; Fig. 6), for the posterior cervical. The C3 of Mongolosaurus (Mannion, 2011, Fig. 7) presents a distally bifid spine, generated by spinous bifid processes formed by parallel longitudinal ridges (sensu Gilmore, 1933). The surface between both metapophyses is transversally concave, and extends anteroposteriorly from the TPRL up to a prominent bony structure located posteromedially to the metapophyses. This bony structure, cylindrical in cross-section and here called as medial tubercle, is projected posteriorly, surpassing the posterior border of the metapophyses, which can be observed in lateral view (Fig. 3A-B, G-H, and $4 \mathrm{~A}-\mathrm{B}$ ). This medial tubercle would represent the attachment area for the intervertebral elastic ligament (Schwarz et al., 2007), cf. Lig. elasticum interespinale and Lig. elasticum interlaminare/Lig. interspinale (Tsuihiji, 2004). The robust postzygapophyses have broad subcircular articular surfaces, slightly inclined laterally, which double in size to the prezygapophyses. The postzygapophyses are connected to the neural spine by means of robust spinopostzygapophyseal laminae (SPOL), to the diapophyses by postzygodiapophyseal laminae (PODL), and one to each other by a thin TPOL. The (SPOL) bifurcates proximally in the spinal sector, generating between them deep and anteroposteriorly elongated pneumatic cavities (Figs. 3G-H and 4A-B). Similar structures are observed in the anterior and middle cervicals of the titanosaur Pitekunsaurus (Filippi and Garrido, 2008), although in the latter such structures are paired or divided by a septum, and present a lesser development. The PODL is single, different from the 
A

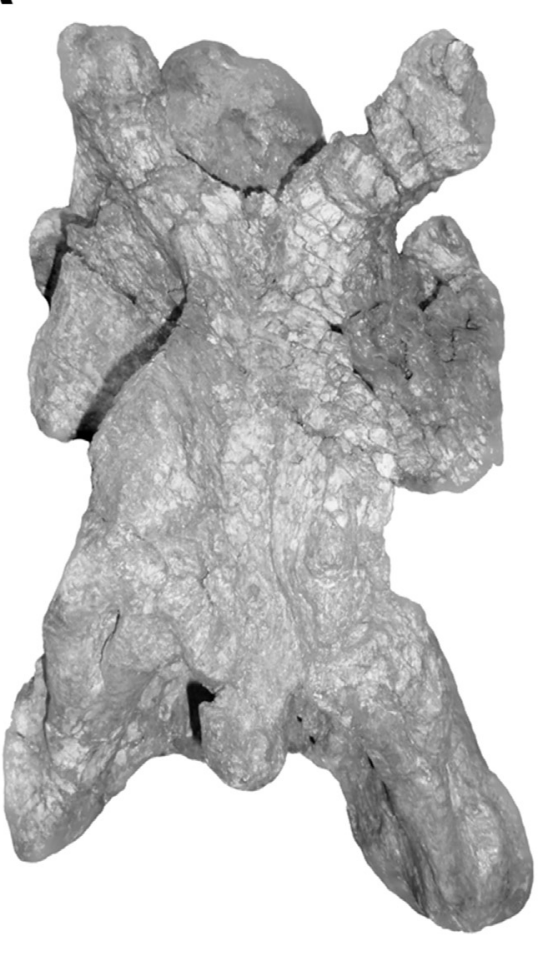

C

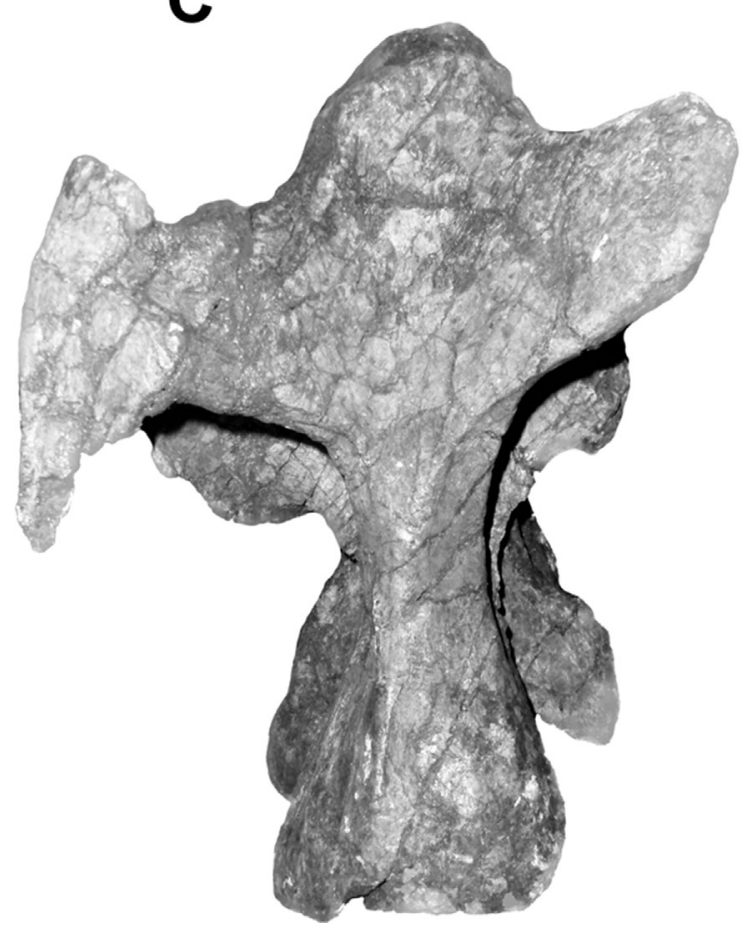

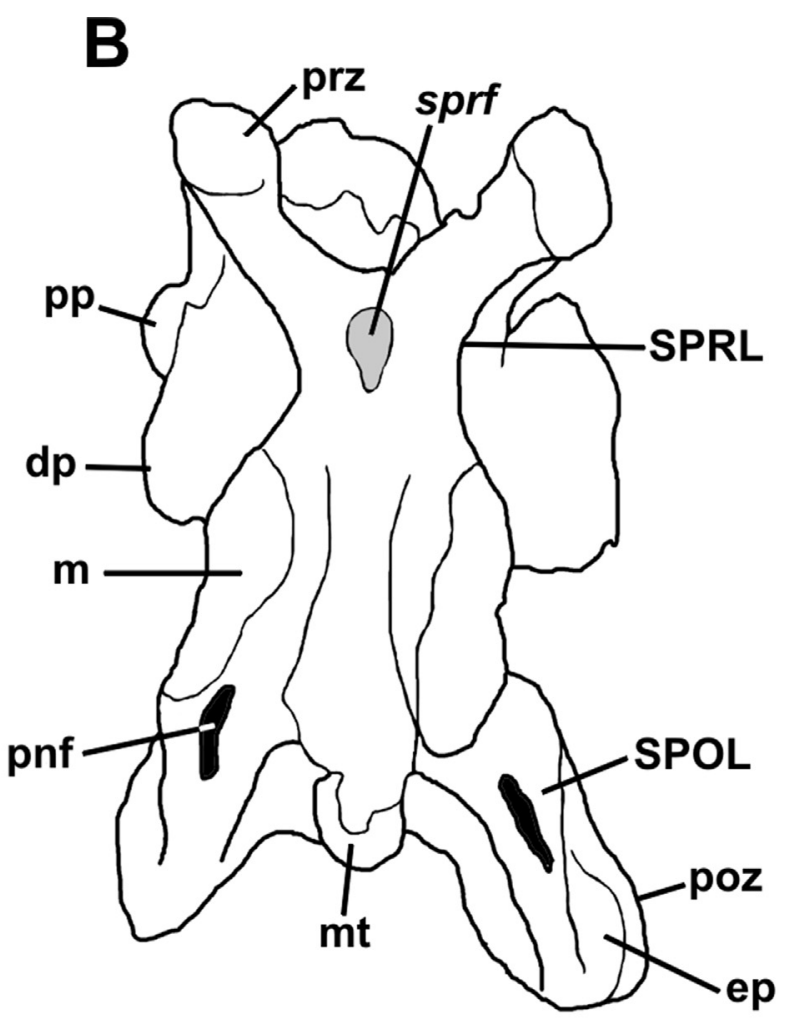

D

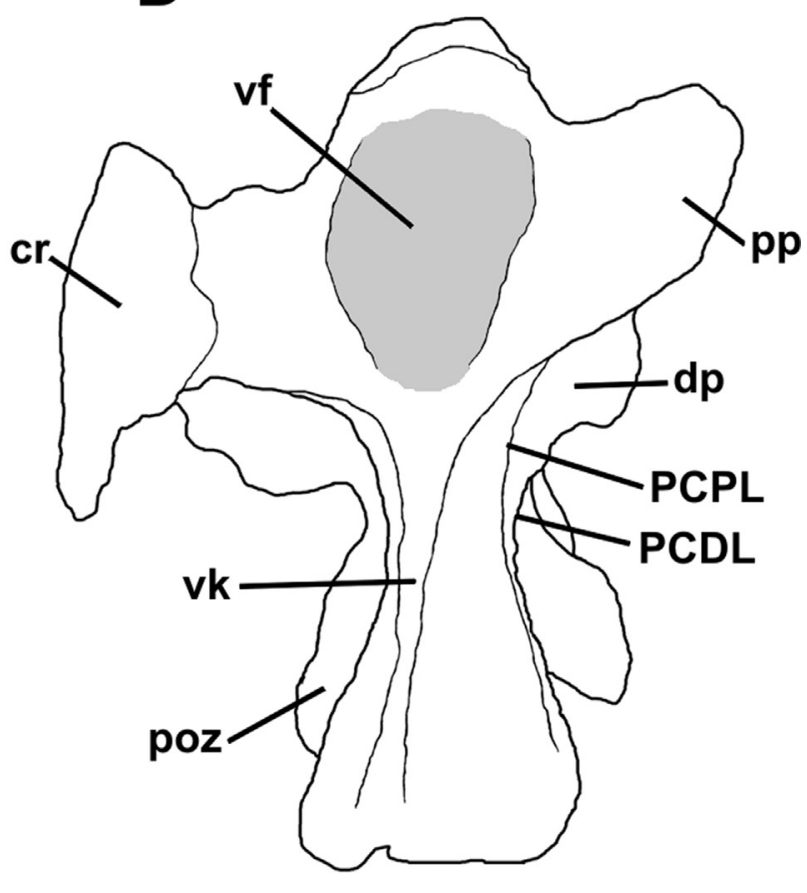

Fig. 4. Anterior cervical vertebra of Kaijutitan maui gen. et sp. nov. MAU-Pv-CM-522/2 (A-B) in dorsal, (C-D) and ventral views. Scale bar: $10 \mathrm{~cm}$. 

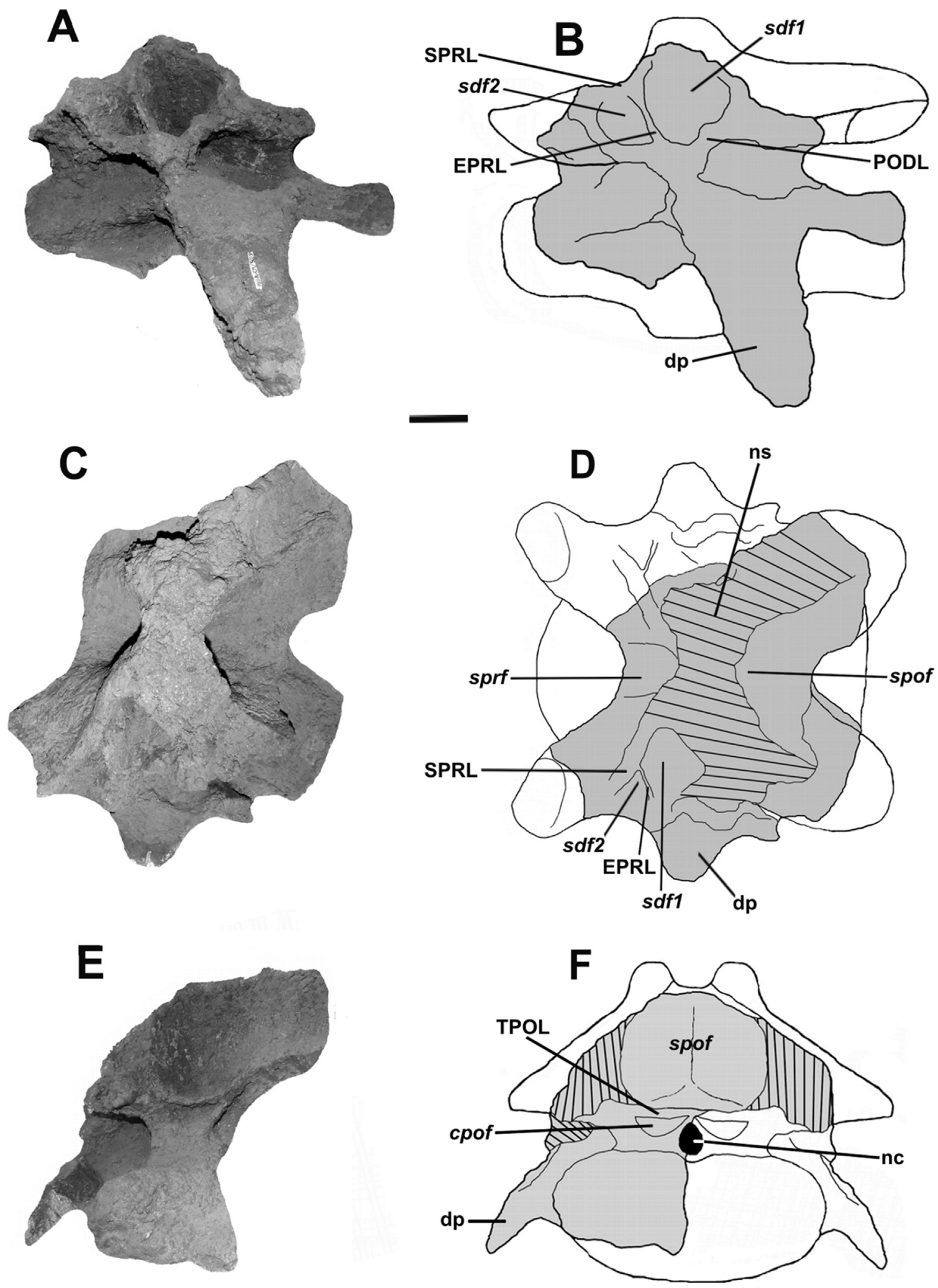

Fig. 5. Posterior cervical vertebra of Kaijutitan maui gen. et sp. nov. MAU-Pv-CM-522/9 (A-B) in left lateral, (C-D), dorsal, (E-F) and posterior views. Scale bar: 10 cm.

diapophyseal and zygapophyseal segments observed in Bonitasaura (Gallina y Apesteguía, 2015), Uberabatitan riberoi (Salgado and Carvalho, 2008) and the specimen "Serie A" of Peirópolis (Powell, 1987). Postzygapophyses present epipophyses, as in Erketu ellisoni (Ksepka and Norell, 2006), but less developed that in Euhelopus zdanskyi (Wilson and Upchruch, 2009), Mongolosaurus and Phuwiangosaurus. The cervical vertebra lacks of an epipophysealprezygapophyseal lamina (EPRL). Posteriorly, between the postzygapophyses and the roof of the neural canal, there is a deep and transversely wide spinopostzygapophyseal fossa (SPOF), which 

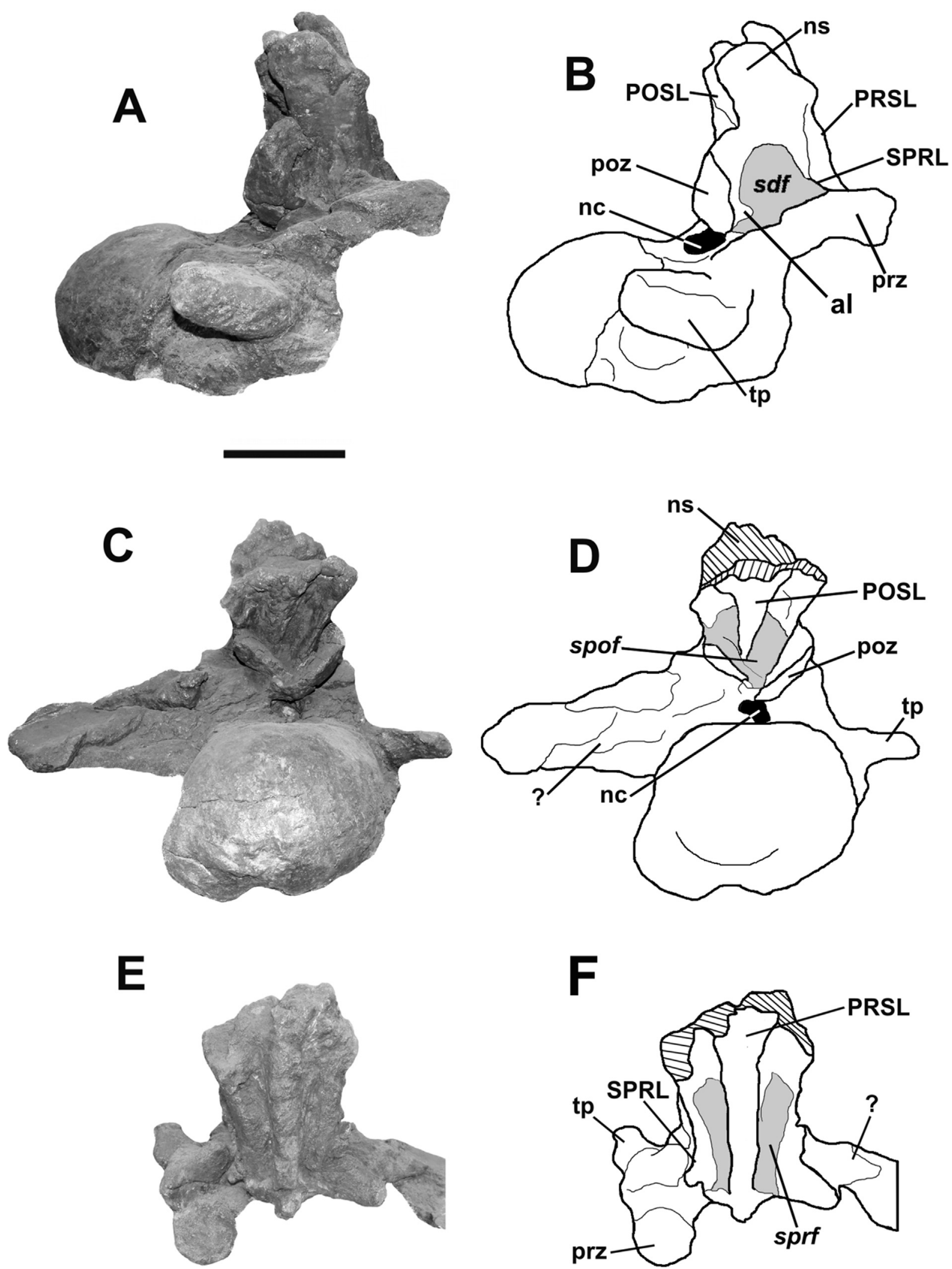

Fig. 6. Anterior caudal vertebra of Kaijutitan maui gen. et sp. nov. MAU-Pv-CM-522/35 (A-B) in right lateral, (C-D), posterior, (E-F) and anterodorsal views. Scale bar: 10 cm. 
A

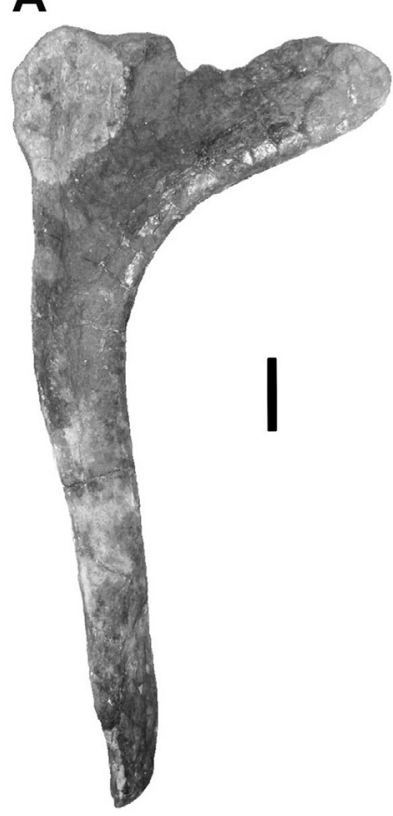

B

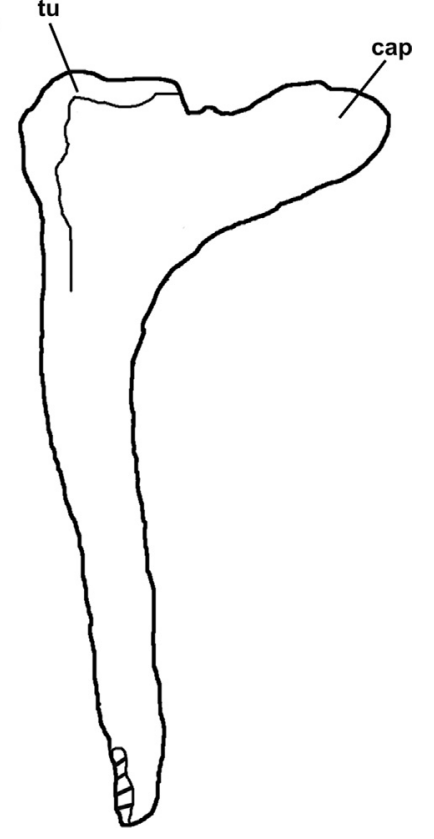

Fig. 7. Anterior dorsal rib of Kaijutitan maui gen. et sp. nov. MAU-Pv-CM-522/8 (A-B) in posterior views. Scale bar: $10 \mathrm{~cm}$.

reaches the mid-length of the vertebral centrum. The articular sector of the right cervical rib has been preserved fused to the parapophysis and diapophysis, while the left proximal portion of the process was unconnected but associated with it. Posteromedially, between the capitulum and the tuberculum, both cervical ribs have a pneumatic foramen. The anterior process of both cervical ribs is short and curved medially. The posterior process of the left rib, at least in the preserved portion, is straight, laminar and presents a ridge at its lateroventral edge that confers a "T" morphology in cross section.

The posterior cervical vertebra (MAU-Pv-CM-522/9), probably the $\mathrm{C} 12$, is very incomplete (Fig. 7). Only part of the left diapophysis and the posterodorsal region of the vertebral centrum are preserved. The dorsoventral inclination of the diapophysis (Fig. 5A-B and E-F) suggests that, as in the anterior cervical, the parapophysis would be ventrally projected, meaning that the cervical rib is located below the level of the vertebral centrum. The vertebra presents well-developed sprf and spof, the latter being the deepest. Although the neural spine has not been preserved, the structure of the base suggests that it would have been transversely wide and anteroposteriorly compressed. Therefore, like the previous cervical vertebra, it could have been bifid with two metapophyses, as in Phuwiangosaurus (Suteethorn et al., 2009). Posteriorly to the SPRL, there is a short lamina attached to it and projected posterodorsally, here interpreted as the EPRL, based on Wilson et al. (2011b) (Fig. 5A-D). The EPRL divides two deep and subtriangular supradiapofiseal fossae, sdf1 and $s d f 2$. As in the anterior cervical, posteriorly, on the left margin of the neural canal, a large, subtriangular cpof is observed. It is delimited by the medial division of the centropostzygapophyseal lamina (mdCPOL), the centropostzygapophyseal lateral lamina (ICPOL), and the TPOL. The cprf and cpof fossae are also present in the posterior cervicals of Overosaurus paradasorum (Coria et al., 2013). On the other hand, the posterior cervical vertebrae of Saltasaurus (personal obs), Bonitasaura (Gallina and Apesteguía, 2015) and Trigonosaurus pricei (Campos et al., 2005) present only the cpof.
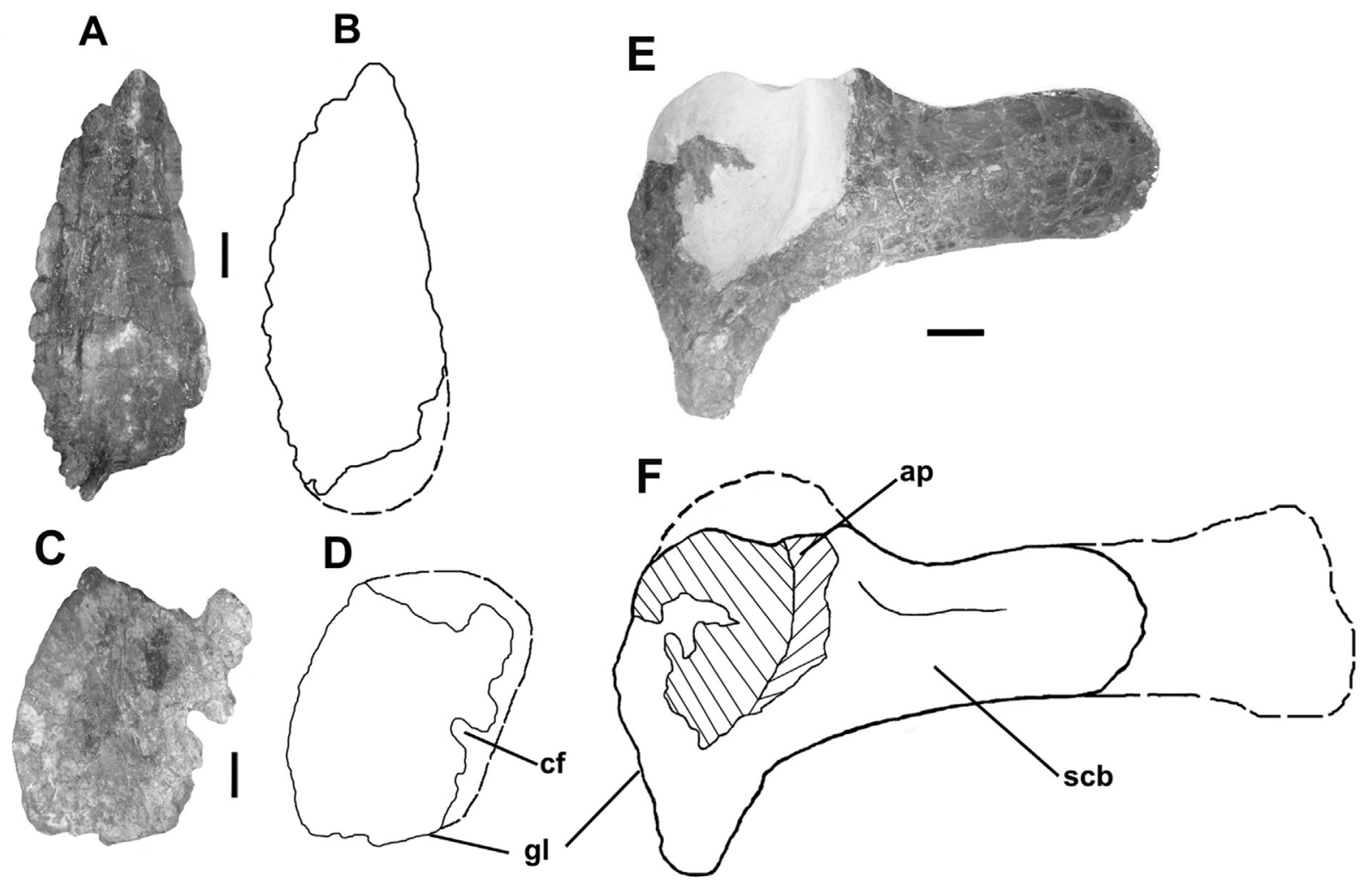

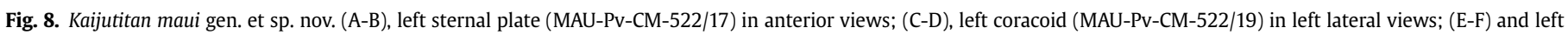
scapula (MAU-Pv-CM-522/21) in left lateral views. Scale bar: $10 \mathrm{~cm}$. 
A

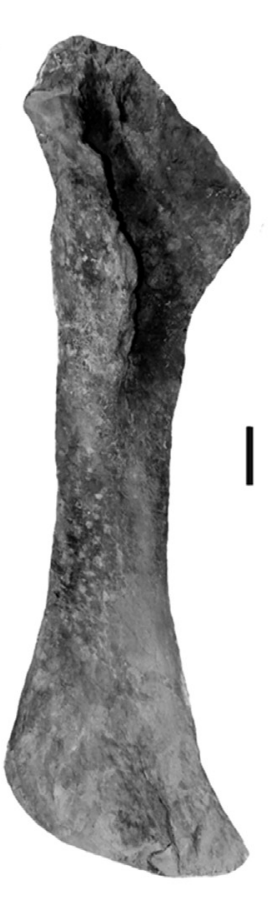

B

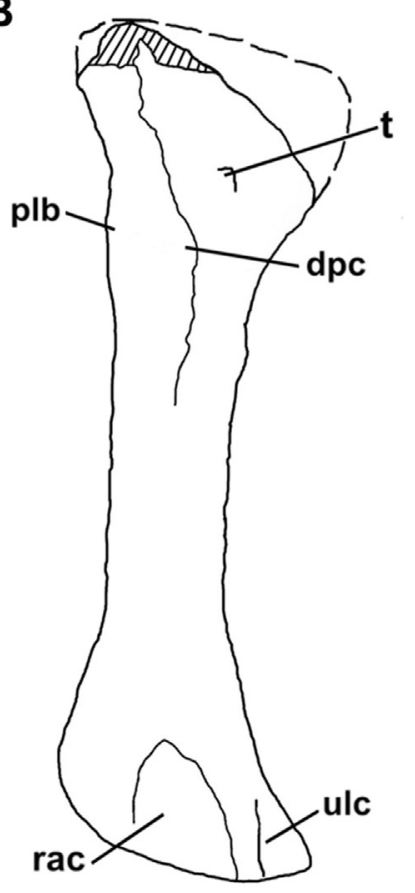

G

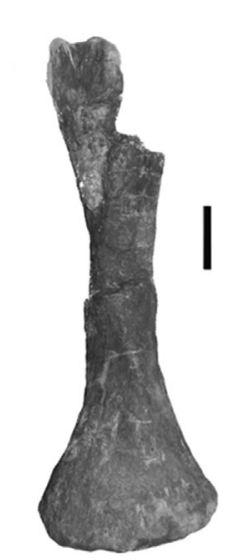

I
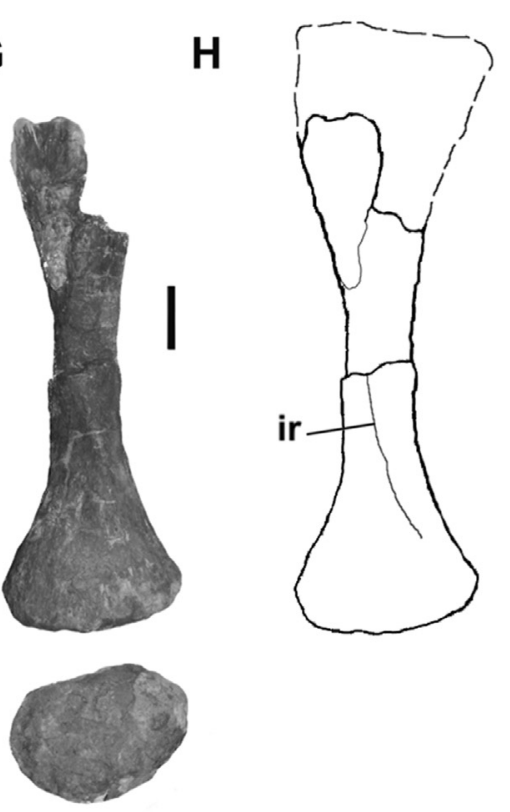

C

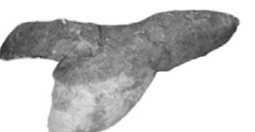

D
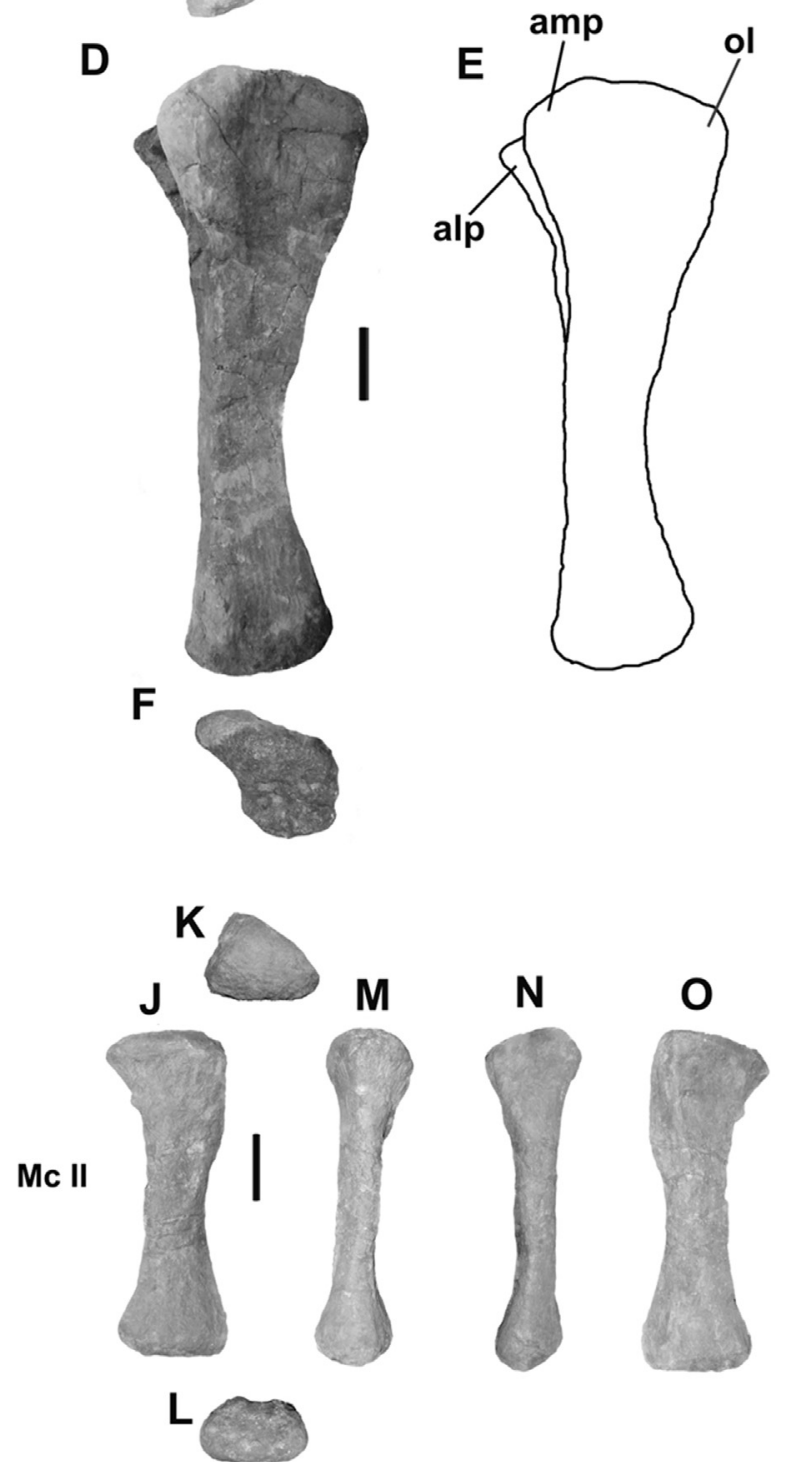

Mc III

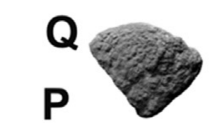

\section{S}
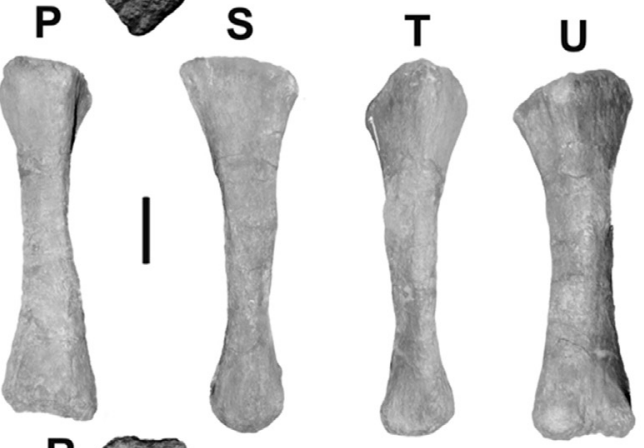

R

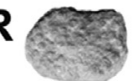

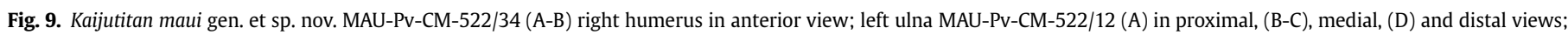

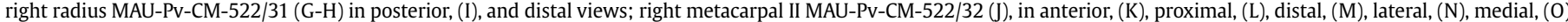
and posterior views; right metacarpal III MAU-Pv-CM-522/33 (P), in anterior, (Q), proximal, (R), distal, (S), lateral, (T), medial, (U) and posterior views. Scale bar: 10 cm. 


\subsubsection{Caudal vertebra}

The anterior caudal vertebra of Kaijutitan maui (MAU-Pv-CM$522 / 35$ ) is procoelous, with the centrum being slightly wider than high (see Table SI4) and with a prominent condyle (Fig. 6C-D). The lateral faces of the centrum are slightly concave anteroposteriorly. They lack of pleurocoels and any other excavations. In posterior view (Fig. 6C-D) is observed a prominence on the left ventral edge, which corresponds to the articular facet for the chevrons. The right transverse processes are well developed and project lateroposteriorly. The tubercle on the dorsal margin present in Baurutitan (Kellner et al., 2005) is not observed in Kaijutitan. The left transverse process presents an indeterminate fused bone that prevents observing its morphology. The neural arch is on the anterior half of the vertebral centrum, almost on the anterior border. The prezygapophyses have subcircular articular surfaces; these are short, robust, and projected anterodorsally with an angle of nearly $45^{\circ}$ with respect to the horizontal. The prezygapophyses lack the expanded articular surfaces that characterize some aeolosaurs, and their cruvature in lateral view is interpreted as a preservation artefact. The prezygapophyses are connected to the spine by short spinoprezygapophyseal laminae. The neural spine is incomplete distally; it is compressed anteroposteriorly as in Patagotitan (Carballido et al., 2017; Fig. 2 I and L) and Bonitasaura (Gallina and Apesteguía, 2015; Fig. 7C), and widens towards its distal end as in Futalognkosaurus (Calvo et al., 2007c, Figs. 16 and 17). It is subsequently tilted at an angle of approximately $95^{\circ}-100^{\circ}$ with respect to the horizontal, as in Giraffatitan (Janesch, 1950; Fig. 3), Phuwiangosaurus (Suteethorn et al., 2009; Fig. 16C), Mendozasaurus (Fig. González Riga, 2003; Fig. 5A, B and E), Malawisaurus (Gomani, 2003; Fig. 14), Baurutitan (Kellner et al., 2005; Fig. 16), Petrobrasaurus (Filippi et al., 2011a; Fig. 5C and E), Rapetosaurus (Curry Rogers, 2009, Fig. 27C and D), Bonitasaura (Gallina and Apesteguía, 2015, Fig. 7C), Muyelensaurus (Calvo et al., 2007b, Fig. 9) and Saltasaurus (Powell, 1992, Fig. 21B). In Narambuenatitan (Filippi et al., 2011b; Fig. 8A-D), Epachthosaurus (Martínez et al., 2004; Fig. 6A) and Neuquensaurus (Salgado et al., 2005; Fig. 6B and $\mathrm{C})$, the anteriormost caudal vertebrae have neural spines with a very marked posterior inclination angle of approximately $140^{\circ}-145^{\circ}$ with respect to the horizontal. Conversely, Trigonosaurus presents anterior caudal vertebrae (Campos et al., 2005, Fig. 25), with the neural spine inclined forward at an angle of approximately $80^{\circ}-85^{\circ}$ with respect to the horizontal. The neural spine presents welldeveloped, robust prespinal and postspinal laminae (Fig 6C-F), as in Mendozasaurus (González Riga, 2003, Fig. 4E and 5A), Patagotitan (Carballido et al., 2017, Fig. 2H and J) and Bonitasaura (Gallina and Apesteguía, 2015; Fig. 7A and B), which extend to the distal end of the neural spine. The postspinal lamina widens distally. The anterior caudal vertebra of Kaijutitan presents a short SPRL similar to that observed in Mendozasaurus and Patagotitan. The articular surfaces of the postzygapophyses are subtriangular and are united to the spine by short SPOL. Both postzygapophyses are united ventrally forming an angle of nearly $45^{\circ}$, delimiting a deep postspinal fossa. The vertebrae lack the hyposphene-hypantrum complex present in the anterior caudals of Epachthosaurus (Martínez et al., 2004, Fig. 7B). Laterally, the neural spine presents a depression (Fig. 6A-B), the spinodiapophyseal fossa ( $s d f$ ), delimited anteriorly by the SPRL and later by the SPOL. Ventrally in this depression, there is evidence of the existence of a thin accesory lamina that join prezygapophyses and postzygapophyses.

\subsubsection{Dorsal ribs}

A left dorsal rib of Kaijutitan (MAU-Pv-CM-522/11), probably the 2nd one, has been preserved (Fig. 7). This assignment is based on comparisons with the titanosaur Overosaurus (Coria et al., 2013; Fig. 7), which preserves the first four pairs of articulated dorsal ribs.
The rib preserves the proximal two thirds, lacking the distal end. As in the 2nd dorsal rib of Overosaurus, the capitulum is twice as long as the tubercle, and is relatively more gracile. The element, formed by the capitulum and the tubercle, has a convex anterior face and a concave posterior face, as in rebbachisaurids, Camarasaurus and Europatitan (Torcida Fernández-Baldor, 2017, Fig. 9), a character interpreted as a neosauropod synapomorphy (sensu Wilson and Sereno, 1998). No pneumatic foramina are observed, unlike most Titanosauriformes. The rib shaft is almost straight with a subtriangular cross section in the proximal sector.

In addition, another dorsal rib has been recovered from the quarry (MAU-Pv-CM-522/27), which is incomplete proximally. Other fragments are MAU-Pv-CM-522/8 and 18. They are compressed and slightly curved lateromedially.

\subsection{Apendicular skeleton}

\subsubsection{Sternal plate}

The left sternal plate of Kaijutitan (MAU-Pv-CM-522/17) is incomplete at its distal end. In spite of this, an oval morphology is inferred (Fig. 8A-B), similar to that present in basal macronarians such as Camarasaurus, basal titanosauriforms such as Giraffatitan, and in other titanosaurs such as Savannasaurus (Poropat et al., 2016; Fig. 4j). This morphology differs from the typical semilunar shape present in most titanosaurs. The medial border is clearly convex while the lateral border is practically straight or subtly concave. The ventral crest, present in many titanosaurs (e.g. Saltasaurus, Epachthosaurus, Lirainosaurus), is absent. The sternal plate/humerus length ratio is approximately 0.63 ( 0.65 or less is state 0 for Character 154 in Upchurch, 1998) as in Camarasaurus, Brachiosaurus, Petrobrasaurus (0.53) and Narambuenatitan (0.65). In derived titanosaurs such as Alamosaurus, Opisthocoelicaudia and Mendozasaurus, the sternal plate/humerus length ratio is 0.75 or greater (Character154, state 1; Upchurch, 1998).

\subsubsection{Coracoid}

The left coracoid of Kaijutitan (MAU-Pv-CM-522/19) is incomplete in the sector of the articulation with the scapula and in its dorsal sector (Fig. 8C-D). It is deeper dorsoventrally than long anteroposteriorly, as in the titanosauriform Sauroposeidon proteles Wedel et al. 2000 (D'Emic, 2013; FWMSH 93B-10-39), "Paluxysaurus jonesi" Rose, 2007; Fig. 21). It has a rounded anteroventral rim, as in Sauroposeidon, Euhelopus, Giraffatitan, Brachiosaurus (Riggs, 1903, Fig. 3), Ruyangosaurus, Dreadnougthus (Lacovara et al., 2014, Fig. 2B), Malawisaurus (Gomani, 2005, Fig. 19C), Rapetosaurus (Curry Rogers, 2009; Fig. 33B), Tapuiasaurus (Zaher et al., 2011; Fig. 5A), also present in most non-somphospondylan sauropods (Wilson, 2002), unlike the quadrangular edge observed in Cedarosaurus (Tidwell et al., 1999, Fig. 6), Rinconsaurus, Quetecsaurus (González Riga and Ortíz, 2014, Fig. 10) and saltasaurids. As in Camarasaurus, Europasaurus, Euhelopus, Malawisaurus, Rapetosaurus and the non-neosauropod sauropods (i.e., Shunosaurus, Patagosaurus, Haplocanthosaurus), the anteroventral border lacks the lip and the infraglenoid fossa observed in the basal macronarian Tehuelchesaurus benitezzi (Rich et al., 1999), the titanosaurs Rinconsaurus, Quetecsaurus and Patagotitan (Carballido et al., 2017; Fig. 2P) and saltasaurids. The poor preservation of the articulation with the scapula prevents to observe whether the coracoid foramen was open or closed.

\subsubsection{Scapula}

The material corresponds to the right scapula (MAU-Pv-CM$522 / 10$ ), incomplete in its anterior edge, the sector of the glenoid cavity and the supraglenoid fossa. The poor preservation impedes to know if the glenoid cavity was deflected medially as many 
A

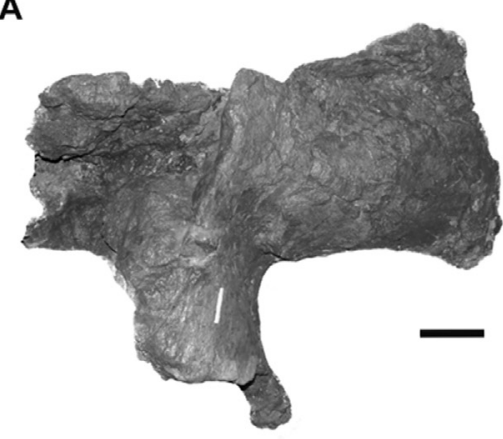

B

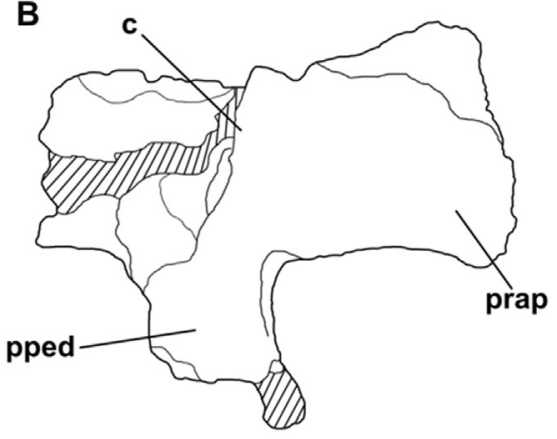

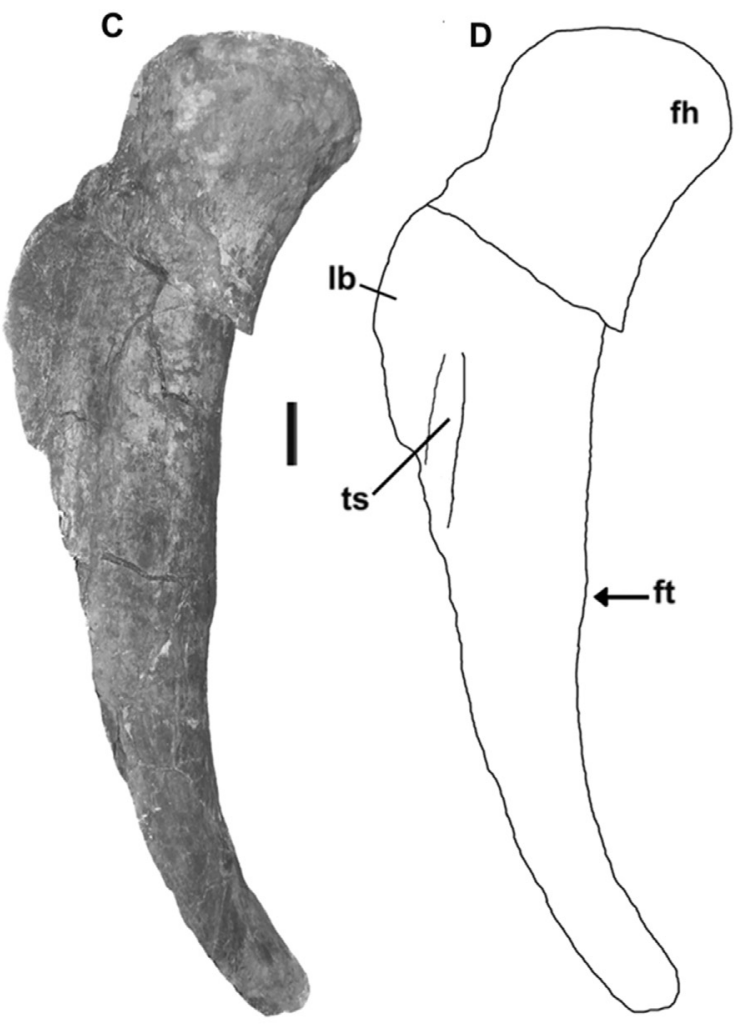

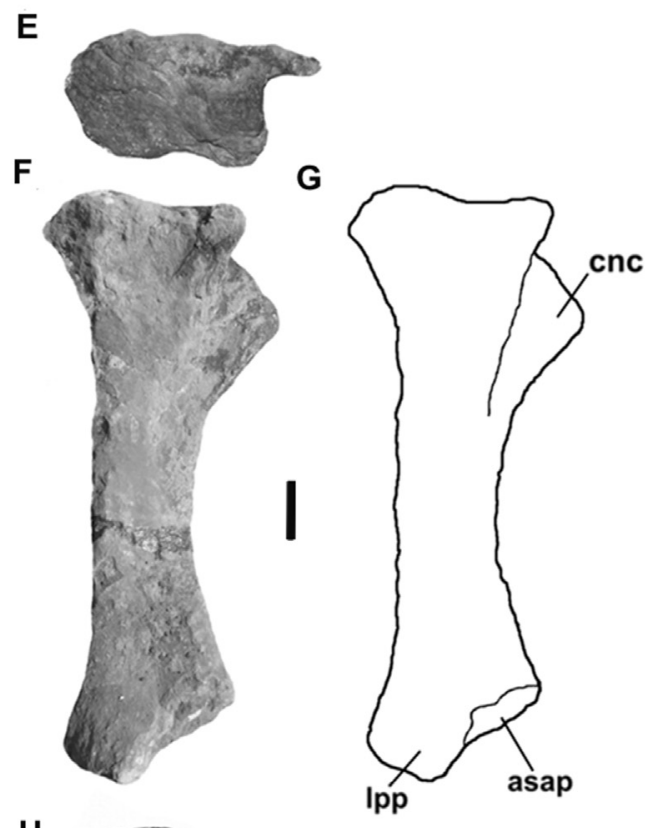

H
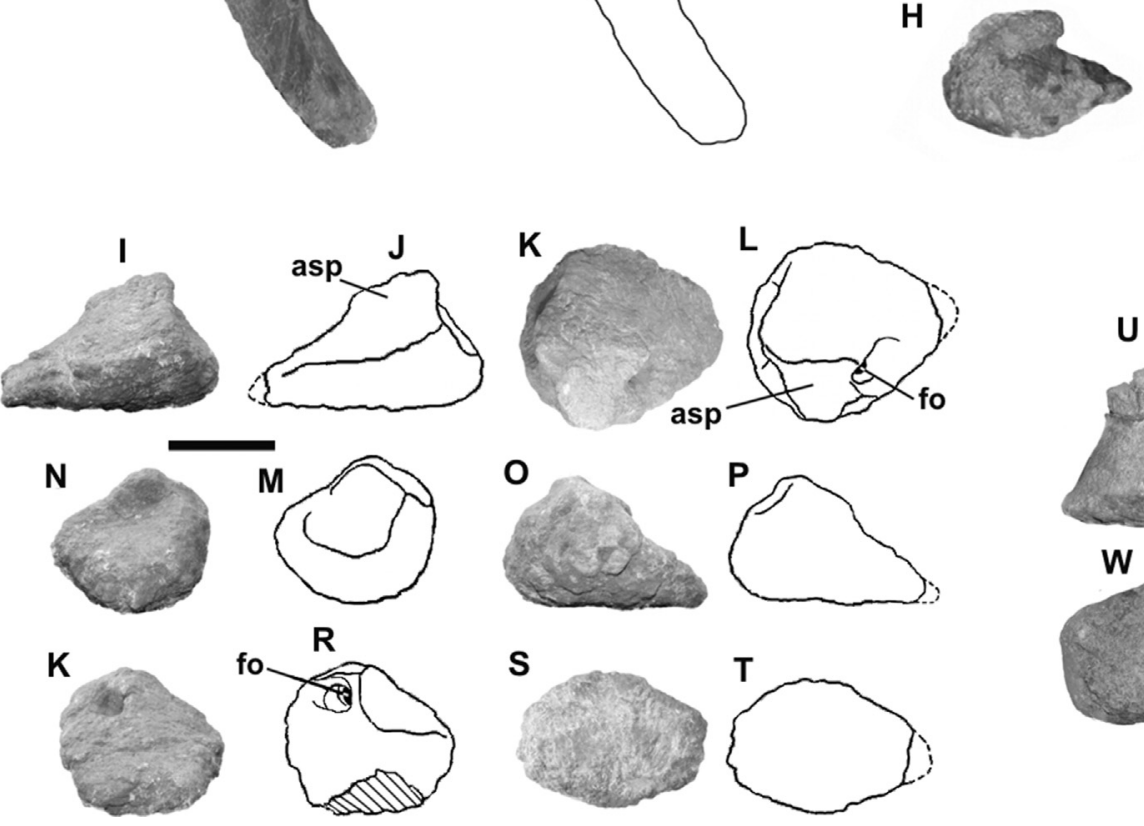

S
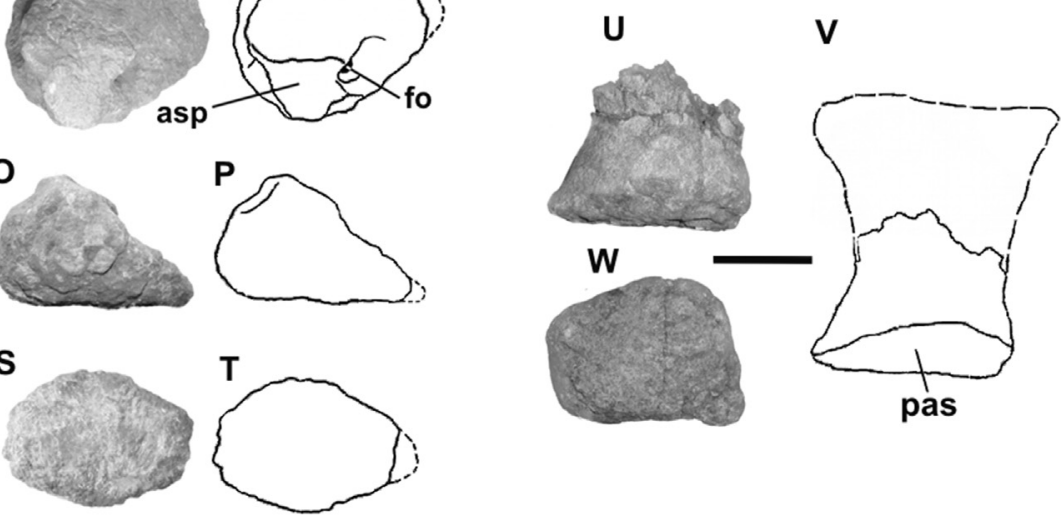

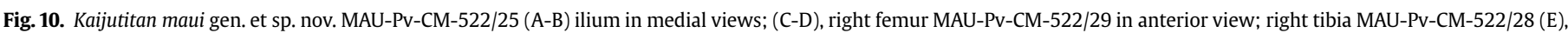

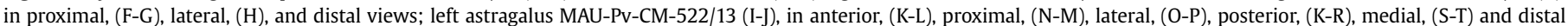
views; right metatarsal II MAU-Pv-CM-522/3 (U-V), in anterior, (W), and distal views. Scale bar: $10 \mathrm{~cm}$. 
titanosaurs. In the same way, it is not possible to observe ridges or processes on the scapular blade. The acromial process and the distal end of the scapular blade are not preserved (Fig. 8E-F). Both the anterodorsal and posteroventral edges of the scapular blade are slightly concave, as in Pitekunsaurus (Filippi and Garrido, 2008, Fig. 8) and Muyelensaurus (Calvo et al., 2007b, Fig 12). The crosssection of the scapular blade presents a "D" shape morphology, as in Ligabuesaurus (Bonaparte et al., 2006), Chubutisaurus (del Corro, 1975) and Antarctosaurus. The medial ventral process observed in Chubutisaurus (Carballido et al., 2011, Fig. 9), Wintonotitan (Hocknull et al., 2009, Fig. 16), Ligabuesaurus (Bonaparte et al., 2006), Vouivria (Mannion et al., 2017; Fig. 16), and Patagotitan (Carballido et al., 2017; Fig. 2P), is absent in Kaijutitan.

\subsubsection{Humerus}

The right humerus of Kaijutitan (MAU-Pv-CM-522/34) is incomplete in its proximal portion (Fig. 9A-B). The shaft is anteroposteriorly compressed in cross section. The deltopectoral extends almost to the mid-length of the diaphysis crest, maintaining the same mediolateral width throughout its entire extension, unlike Isisaurus colberti (Jain and Bandyopadhyay, 1997; Fig. 20), where the crest is very short and restricted to the proximal third of the humerus. The deltopectoral crest is strongly inclined medially, as in Opisthocoelicaudia, Gondwanatitan (Kellner and Azevedo, 1999; Fig. 20), Mendozasaurus (González Riga, 2003; Fig. 5I; González Riga et al., 2018; Fig. 14B) and Petrobrasaurus (Fig. Filippi et al., 2011a, Fig. 6A), differing from the slight medial inclination observed in Malawisaurus and Chubutisaurus. In many sauropods such as Ligabuesaurus (Bonaparte et al., 2006; Fig. 6A), Alamosaurus, Narambuenatitan (Filippi et al., 2011b; Fig. 10B), Rinconsaurus, Muyenlensaurus (Calvo et al., 2007b; Fig. 12B), Malawisaurus, Rapetosaurus (Curry Rogers, 2009; Fig. 35A) and Saltasaurus, the deltopectoral crest is anteriorly projected. On the anterior surface of the proximal third, a slightly tuberosity is observed, which is interpreted as attachment of the M. coracobrachialis, as in Patagotitan (Carballido et al., 2017; Fig. 2Q), Ruyangosaurus, Diamantinasaurus (Poropat et al., 2015; Fig. 10A) and Neuquensaurus (Otero, 2010). On the lateral margin of the posterior surface, leveled with the most prominently developed portion of the deltopectoral crest, a strong bulge is observed, which is interpreted as the area for insertion of the M. scapulohumeralis anterior, as in Opisthocoelicaudia (Borsuk-Bialynicka, 1977; Fig. 7C and D), Notocolossus (González Riga et al., 2016; Fig. 4A), Patagotitan (Carballido et al., 2017; Fig. 2R), Wintonotitan (Poropat et al., 2014; Fig. 8C), Mendozasaurus (González Riga et al., 2018) and Narambuenatitan. The distal end of the humerus presents a slight medial torsion with respect to the proximal end. Distally, the radial condyle is more developed than the ulnar condyle, as in Petrobrasaurus and $\mathrm{Neu}$ quensaurus. In Rapetosaurus, the ulnar condyle is slightly larger than the radial condyle (Curry Rogers, 2009). The condyles are separated by a shallow groove as in Chubutisaurus and different to the well development fossa present in saltasaurines (Otero, 2010).

\subsubsection{Ulna}

The left ulna of Kaijutitan (MAU-Pv-CM-522/12) (Fig. 9C-F) is moderately robust, with a robustness index of 0.24 , similar to Rapetosaurus (0.23), lesser than Neuquensaurus (0.29) and Yongjinglong datangi (Li -Guo Li et al., 2014; Fig. 13 and 14) (0.33) and greater than Argyrosaurus (0.19). In proximal view, the ulna is triradiate, a configuration conferred by the olecranon and the anteromedial and anterolateral processes. The olecranon process is not prominent, and it is located approximately at the level of the anteromedial and anterolateral processes (Fig. 9D-E), as in Camarasaurus, Europasaurus, Bonitasaura and Dreadnoughtus schrani (Lacovara et al., 2014). The anteromedial process have a similar length than the anterolateral process (Fig. 9C), as in Diamantinasaurus (Poropat et al., 2015; Fig. 11F), Malawisaurus and Argyrosaurus superbus Lydekker (1893) and different from Rapetosaurus, Elaltitan lilloi (Mannion and Otero, 2012; Fig. 7E), Narambuenatitan (Filippi et al., 2011a,b; Fig. 10A1), Pitekunsaurus, Muyelensaurus and Neuquensaurus (Otero, 2010; Fig. 4A5) where the anteromedial processes is longer that the anterolateral process. The anteromedial process is concave in medial and lateral views, a condition that is present in several titanosauriforms (Poropat et al., 2014). The anterolateral process is almost parallel to the olecranon process. This position might have been affected by crushing. The radial surface of the ulna is concave. The distal end is oval, as in Narambuenatitan (Filippi et al., 2011a,b; Fig. 10 A3) and different from Rapetosaurus (Curry Rogers, 2009; Fig. 37E), Diamantinasaurus (Poropat et al., 2015; Fig. 11H), Elaltitan (Mannion and Otero, 2012; Fig. 7F) and Pitekunsaurus, where it is rather circular. The distal end of the ulna has a depression on its anteromedially face (Fig. 9F), where it would articulate with the radius.

\subsubsection{Radius}

The distal two-thirds of the right radius of Kaijutitan (MAU-PvCM-522/31) is preserved (Fig. 9G-I). The distal end of the radius is robust and widened in relation to the narrow and slender shaft, which is subeliptic in cross-section. The distal articular face is oval, with the major axis lateromedially oriented, as in Diamantinasaurus (Poropat et al., 2015, Fig. 12B), Mendozasaurus (González Riga et al., 2018, Fig. 16D), Bonitasaura (Gallina and Apesteguía, 2015; Fig. 12C) and Neuquensaurus (Otero, 2010; Fig. 5A7), and different from Argyrosaurus (Mannion and Otero, 2012; Fig. 2E), where it is subtriangular and slightly expanded. The distal end is approximately twice the minimum width of the diaphysis as in Chubutisaurus (Carballido et al., 2011). The distal lateral end is beveled as in Diamantinasaurus (Poropat et al., 2015; Fig. 12) and Bonitasaura salgadoi (Gallina and Apesteguía, 2015; Fig. 12A and B). This beveling is also present in several somphospondyls (Wilson, 2002; Mannion et al., 2013) and in several basal eusauropods (Mannion et al., 2013; Mateus et al., 2014). In the distal third of the diaphysis, on the posterior face, a short ridge is observed, which would correspond to the interosseous ridge present in other titanosaurs, as Rapetosaurus (Curry Rogers, 2009; Fig. 36), Mendozasaurus (González Riga et al., 2018; Fig. 16 C), Bonitasaura (Gallina and Apesteguía, 2015; Fig. 12 B) and Neuquensaurus (Otero, 2010; Fig. 5).

\subsubsection{Metacarpus}

Only the right metacarpals II and III (MAU-Pv-CM-522/32 and 33) (Fig. 9J-U), have been recovered, complete and in a very good state of preservation (Fig. 14). Metacarpal III is longer than metacarpal II, as in Sauroposeidon ("Paluxysaurus jonesi" Rose, 2007), Rapetosaurus (Curry Rogers, 2009, Fig. 38), Wintonotitan (Poropat et al., 2014) and many other sauropods (Upchurch, 1998). On the contrary, in Camarasaurus sp. SMA 0002 (Tschopp et al., 2015), Alamosaurus (Gilmore, 1946), Argyrosaurus (Mannion and Otero, 2012, Fig. 3) and Petrobrasaurus (Filippi et al., 2011a, Fig. 6D), metacarpal II is the longest. In Mendozasaurus (Gonzalez Riga et al., 2018) the longest metacarpal is metacarpal IV, followed by metacarpals II and III, of equal length. The distal end of metacarpals II and III does not show the presence of joint surfaces for phalanges, as in Camarasaurus (Tschopp et al., 2015) and Giraffatitan ("Brachiosaurus", Janesch, 1914).

Metacarpal II. (Fig. 9J-O) Metacarpal II of Kaijutitan presents a straight diaphysis with the ends proportionally widened, as in Dimantinasaurus (Poropat et al., 2015; Fig. $13 \mathrm{M}$ and J), and Rinconsaurus (Calvo and González Riga, 2003), while metacarpal II of Bonitasaura (Gallina and Apesteguía, 2015; Fig. 12), Neuquensaurus and Petrobrasaurus (Filippi et al., 2011a; Fig. 6D), shows a slight 
widening only at its proximal end. The proximal end, which is slightly convex, and the flat distal end have rough surfaces. In crosssection, the proximal end is subtriangular and the distal end is subrectangular, as in Petrobrasaurus, Wintonotitan (Poropat et al., 2015; Fig. 15 B), and Mendozasaurus (González Riga et al., 2018; Fig. 18G), unlike the distal quadrangular end observed in Bonitasaura. The posteromedial face for the articulation with metacarpal I is proximally concave as in Bonitasaura and Rinconsaurus, as well as the posterolateral face for the articulation with metacarpal III. The anterior face is practically flat. On the proximal third of the posteromedial face there is a turbeculum, which is probably for the insertion of the ligaments of the flexor muscles of the hand (M. flexores digitorum profundi, sensu Otero, 2018).

Metacarpal III. (Fig. 9P-U) Like metacarpal II, metacarpal III of Kaijutitan has a straight diaphysis with its ends widened, as in Diamantinasaurus (Poropat et al., 2015; Fig. 13M and J), Mendozasaurus (González Riga et al., 2018; Fig. 18P) and Chubutisaurus (Carballido et al., 2011; Fig. 12). The proximal and distal ends have rough surfaces, while the proximal surface is slightly convex and the distal surface relatively flat. The proximal end is subtriangular in cross-section, while the distal one is subquadrangular, as in Chubutisaurus, Epachthosaurus (Martinez et al., 2004, Fig. 10) and Argyrosaurus (Mannion and Otero, 2012, Fig. 3D), and unlike Diamantinasaurus (Poropat et al., 2015; Fig. 13P), Wintonotitan (Poropat et al., 2014; Fig. 16B), Aeolosaurus sp. MPCA-27100 (Salgado et al., 1997; Fig. 4A) and Mendozasaurus (González Riga et al., 2018; Fig. 18M), where it is subrectangular. The posteromedial face for the articulation with metacarpal II is slightly concave, as in Rinconsaurus, while the posterolateral face for the contact with metacarpal IV is slightly convex as in Bonitasaura. On the proximal third of the posteromedial face, there is the turbeculum for the insertion of ligaments for the flexor muscles of the hand $(\mathrm{Mm}$. flexores digitorum profundi, sensu Otero, 2018), also observed in metacarpal II.

\subsubsection{Ilium}

A fragment of bone (MAU-Pv-CM-522/25) is interpreted as part of a left ilium (Fig. 10A-B). The fragment consists in part of the preacetabular process, the proximal sector of the pubic pedicel and part of the iliac blade. Although the bad preservation of the material prevents a detailed description, it is possible to infer that the preacetabular process was recurved and expanded laterally, as in other titanosauriforms such as Ruyangosaurus (Lu et al., 2014; Fig. 3-14A), Epachthosaurus (Martínez et al., 2004; Fig. 11A), Rapetosaurus (Curry Rogers, 2009; Fig. 39), Trigonosaurus (Campos et al., 2005; Fig. 21), Rinconsaurus (Calvo and González Riga, 2003; Fig. 3B) and Overosaurus (Coria et al., 2013; Fig. 5A). The pubic pedicel is relatively long. Its anterior surface is convex and its posterior surface, which is part of the acetabulum, is concave. On the dorsal edge of the pubic pedicel there is a prominent crest, which corresponds to the articulation with the second sacral rib, as observed in Rapetosaurus (Curry Rogers, 2009; Fig. 39A), Muyelensaurus (MAU- Pv-LL432) and Rinconsaurus (MAU-Pv-CRS-275/2).

\subsubsection{Femur}

The left femur of Kaijutitan (MAU-Pv-CM-522/29) is incomplete in two sectors: laterodistally and in the area of the greater trochanter (Fig. 10C-D). The diaphysis is anteroposteriorly compressed and elliptical in cross-section, but also has undergone some crushing. The femoral head projects dorsomedially: it is prominent, robust, with the rough articular surface. In the proximal portion, on the posterolateral surface, the femur presents a ridge, which corresponds to the trochanteric shelf, present in sauropods such as Neuquensaurus (Otero, 2010, Fig. 1A3 and A4), Mendozasaurus, Petrobrasaurus, Rapetosaurus (Curry Rogers, 2009; Fig. 43C) and Pitekunsaurus. The lateral protuberance, very noticeable, is placed on the lateral edge of the diaphysis, below the position where the greater trochanter would be, as in other Titanosauriformes (Salgado et al., 1997; Wilson and Sereno, 1998). The fourth tronchanter is located posteriorly on the caudomedial margin of the shaft. Although the femur is not complete, it would be placed near to the middle of the shaft, as in Giraffatitan, Chubutisaurus (Carballido et al., 2011; Fig. 14A and B), Ligabuesaurus, Ruyangosaurus (Lu et al., 2014; Fig. 3-19B), Epachthosaurus (Martínez et al., 2004; Fig. 12A), Rinconsaurus (Calvo and González Riga, 2003; Fig. 3C) and Mendozasaurus. On the contrary, in Brachiosaurus, Phuwiangosaurus (Martin et al., 1999; Fig. 18-2), Rapetosaurus (Curry Rogers, 2009; Fig. 43B and C), Bonitasaura, Patagotitan (Carballido et al., 2017, Fig. 2S), Petrobrasaurus, Narambuenatitan (Filippi et al., 2011b, Fig. 11A), Neuquensaurus (Otero, 2010, Fig. 10A3 and A4) and Saltasaurus, the fourth trochanter is located on the proximal third of the diaphysis. There is no evidence for a midline ridge (intermuscularis cranialis line) on the anterior surface of the shaft.

\subsubsection{Tibia}

The right tibia of Kaijutitan (MAU-Pv-CM-522/28) is almost complete, lacking only part of the distal end (Fig. 10E-H). Both ends are well developed, with the proximal end enlarged as in other sauropods. It is a relatively robust bone (see robustness index in Table SI5, Supplementary information), like that of Chubutisaurus (Carballido et al., 2011), Ophisthocoelicaudia, Neuquensaurus (Otero, 2010) and Saltasaurus, unlike the gracile tibia of other sauropods such as Jainosaurus (Wilson et al., 2011a) and Laplatasaurus (Gallina y Otero, 2015). The proximal end is lateromedially compressed, with the articular surface subrectangular (Fig. 10E), different from the oval contour present in Ruyangosaurus (Lu et al., 2014; Fig. 3.21B), Petrobrasaurus (Filippi et al., 2011a; Fig. 6G), Rapetosaurus (Curry Rogers, 2009; Fig. 44E), Bonitasaura (Gallina and Apesteguía, 2015; Fig. 15E) and Mendozasaurus (González Riga, 2003; Fig. 6A), and the subcircular contour observed in other sauropods such as Tastavinsaurus (Canudo et al., 2008; Fig. 14E), Gobititan (You et al., 2003; Fig. 2), Ligabuesaurus, Chubutisaurus (Carballido et al., 2011, Fig. 15C), Diamantinasaurus (Poropat et al., 2015; Fig. 20B), Jainosaurus (Wilson et al., 2011a; Fig. 7E), Laplatasaurus (Gallina y Otero, 2015; Fig. 2.5), Uberabatitan (Salgado and Carvalho, 2008, Fig. 19B) and Neuquensaurus (Otero, 2010, Fig. 11A6). The cnemial crest is triangular (Fig. 16D-E), as in Laplatasaurus, Bonitasaura (Gallina and Apesteguía, 2015; Fig. 15D) and Neuquensaurus, different from the curved cnemial crest present in Chubutisaurus (Carballido et al., 2011, Fig. 15A), Lirainosaurus (Díez Diaz et al., 2013; Fig. 5, 6 and 7), Diamantinasaurus (Poropat et al., 2015; Fig. 20C and E), Petrobrasaurus (Filippi et al., 2011a, Fig. 6HI) and Bonatitan (Salgado et al., 2014; Fig. A and B). The cnemial crest is anteriorly projected, as in Turiasaurus (Royo-Torres et al., 2006) and Patagosaurus fariasi (Bonaparte, 1979), and different from the anterolateral projection observed in most eusauropods (Wilson and Sereno, 1998). Posterolaterally to the cnemial crest, the tibia lacks the protuberance present in Uberabatitan (Salgado and Carvalho, 2008, Fig. 19B) and Opisthocoelicaudia (BorsukBialynicka, 1977: pl. 14). Laterally on the cnemial ridge, there is a concave depression corresponding to the articular surface for the proximal end of the fibula. The distal end is similar to Chubutisaurus, with the posteroventral process reduced and the articular surface for the ascending process of the astragalus well developed, forming a step-like shape (Carballido et al., 2011).

\subsubsection{Astragalus}

The left astragalus of Kaijutitan (MAU-Pv-CM-522/13) (Fig. 10 I$\mathrm{T}$ ) is well preserved but incomplete in its medial portion. The astragalus exhibits the wedge morphology observed in other 
Neosauropoda (Upchurch, 1995, 1998). It is wider (mediolaterally) than high (proximodistally), as in Janeschia robusta (Bonaparte et al., 2000; Figs. 6 and 7), Camarasaurus grandis (Wilson and Sereno, 1998; Fig. 33), Giraffatitan and Lusotitan atalaiensis (Mannion et al., 2013; Fig. 19), lacking the pyramidal morphology present in most titanosaurs (Wilson, 2002). In proximal view, the astragalus is subtriangular, tapering medially.The anterior and lateral edges are rounded, differing from the straight edges observed in Bonitasaura and Diamantinasaurus. The surface of the astragalus, especially its distal surface, is rugose probably due to the presence of cartilage. The ascending process, although distally incomplete, is relatively prominent, but not so as in Uberabatitan (Salgado and Carvalho, 2008) and Savannasaurus elliotorum (Poropat et al., 2016). Because the ascending process is distally incomplete, it is not possible to know if it was posteriorly projected. At the base of the ascending process, the astragalus presents a wide, undivided subcircular pit, within which there is a single foramen, as in Giraffatitan, Bonitasaura, Neuquensaurus, Opisthocoelicaudia, Epachthosaurus and Notocolossus, a different condition from the divided fossa present in basal macronarians and diplodocoids (Gallina and Apesteguía, 2015). The lateral side of the ascending process presents a slightly concave surface for the contact with the distal end of the fibula, which lacks a laterally directed ventral shelf as observed in most sauropods (e.g. Notocolossus, Uberabatitan, Diamantinasaurus) and absent in several titanosauriformes like Euhelopus, Giraffatitan and Gobititan (Mannion, 2013). In specimen MUCPV-1533 (González Riga et al., 2008), this concavity is present but is less marked. The articular surface for the tibia is inclined medially in a relatively marked angle, as in Aeolosaurus sp. (Salgado et al., 1997), although at a lower angle than in Uberabatitan and Savannasaurus. While in saltasaurids the astragalus is transversely reduced, covering only a part of the surface of the distal end of the tibia (e.g. Opisthocoelicaudia 54\% and Neuquensaurus 56\%, Salgado and Carvalho, 2008), the astragalus of Kaijutitan would cover a larger surface, probably $80 \%$, being similar to that observed in Gobititan shenzhouensis (You et al., 2003; Fig. 2) and Erketu (Ksepka and Norell, 2006; Fig. 10). In Euhelopus (Wilson and Upchurch, 2009, Fig. 25), the astragalus covers completely the distal end of the tibia. Ventrally, the astragalus presents a convex rough surface, as in Giraffatitan, Euhelopus, Erketu, Gobititan, Opisthocoelicaudia and Bonitasaura, probably for articulation with the metatarsals II and III.

\subsubsection{Metatarsus}

Only the distal portion of the right metatarsal II of Kaijutitan has been preserved (MAU-Pv-CM-522/3) (Fig. 10U-W). Although it is incomplete, it is observed that the preserved portion of the diaphysis is dorsoplantarly compressed, as in the basal macronarian Camarasaurus (SMA 0002, Tschopp et al., 2015) and the titanosaurs Gobititan, Muyelensaurus and the specimen NMMNH P4996 (D'Emic et al., 2011). The distal articular surface is rugose, as in most sauropods (e.g. Ligabuesaurus, Muyelensaurus, MUCPv-1533 and Notocolossus), probably owed to the existence of cartilage. The distal articular surface is quadrangular and has a projection in its ventromedial corner, which is visible in distal view, similar to that observed in metatarsal II of the NMMNH P-4996 (D'Emic et al., 2011, Fig. 2) and Notocolossus (González Riga et al., 2016; Supplementary Fig. S7). Also in distal view, the articulation surface for the phalanx is asymmetric, with the dorsal edge more extended medially than lateraly, as in most sauropods, for instance Apatosaurus ajax (Upchurch et al., 2004), Gobititan (You et al., 2003, Fig. 2) and Notocolossus (González Riga et al., 2016, Supplementary Fig. S7). As in other sauropods (e.g. Rapetosaurus, Muyelensaurus, Notocolossus, NMMNH P-4996, MUCPv-1533), the distal articular surface has a convex dorsal region and a concave plantar region.

\section{Discussion}

\subsection{Phylogenetic analysis}

In order to establish the phylogenetic relationships of Kaijutitan, an analysis was performed based on the data matrix published by Carballido et al. (2017), consisting of 87 taxa and 405 characters. From this matrix, thirteen unstable taxa (Isanosaurus, Tehuelchesaurus, Venenosaurus, Cedarosaurus, Tastavinsaurus, Lusotitan, Padillasaurus, Malarguesaurus, Quetecsaurus, Drusilasaura, Puertasaurus, Bonitasaura and Trigonosaurus) were excluded a priori. On the other hand, a number of existing characters were modified (see Supplementary information). The character scores for Ruyangosaurus were revised based on Lü et al. (2014), Tapuiasaurus based on Wilson et al. (2016), while the rest of the specimens were revised based on the original bibliography and direct observations on the materials. The program used to analyze the data was the software T.N.T. 1.5 (Goloboff and Catalano, 2016). Characters were ordered as in the original analysis. The chosen parameters included the algorithm of Tree bisection reconnection (TBR), with 10000 replications of Wagner trees and 10 trees to save per replication.This procedure retrieved 40 most parsimonious trees (MPTs) of 1296 steps $(\mathrm{CI}=0.38$; $\mathrm{RI}=0.71$ ), found in 1223 of the replicates. (The strict consensus of both analyses is illustrated in the Supplementary information).

The strict consensus shows a polytomy at the base of Saltasauridae, but it is resolved pruning Nemegtosaurus.

Kaijutitan maui is recovered as a basal titanosaur, the sister taxon of Epachthosaurus + Eutitanosauria (sensu Salgado, 2003) (Fig. 11). Only one character supports this group: procoelous anterior caudal vertebra (character 231, state 3). Whereas the group of Epachthosaurus + Eutitanosauria, is supported by astragalus shape with subequal anteroposterior and transverse dimensions (character 372, state 1 ).

Other positions of Kaijutitan were tested. First, a position within Lithostrotia was forced, resulting in 80 trees of 1303 steps, that is, seven steps longer than the most parsimonious tree. When Kaijutitan was forced into a position within Eutitanosauria, resulted 40 trees of 1297 steps, only one step longer than the most parsimonious tree. In sum, the hypothesis that Kaijutitan is a basal titanosaur is weakly supported, since with a single step it is located within Eutitanosauria.

The inclusion of Kaijutitan in the matrix of Carballido et al. (2017) has affected other taxa: Wintonotitan is recovered as a basal Titanosauria, but closely related as a sister taxon of Andesaurus. In turn, Ruyangosaurus is located in a more derived position as a basal Eutitanosauria, different from the proposal hypothesis of Carballido et al. (2017), where Ruyangosaurus is recovered as a basal Titanosauria. This phylogenetic positions differs from the one presented by Lü et al. (2014), in which Ruyangosaurus is a basal Somphospondyli. The new topology with Ruyangosaurus in a new position is probably due to the character modification and the inclusion of Kaijutitan.

\subsection{Body mass estimation}

The body mass of quadrupedal dinosaurs can be estimated using femoral and humeral circumferences, through scaling equations and volumetric methods (Campione and Evans, 2012; Benson et al., 2014). Unfortunately, the femur and humerus of Kaijutitan maui are incomplete, which makes impossible to make such a calculation. However, by comparisons with measurements taken from other titanosauriforms (Giraffatitan, Brachiosaurus, Sauroposeidon, Ligabuesaurus, Ruyangosaurus, Sarmientosaurus, Antarctosaurus, Narambuenatitan, Pitekunsaurus, Notocolossus, Dreadnougthus and Patagotitan, see measurements table 2 and 3 in Supplementary information), it is possible to estimate the probable body mass of Kaijutitan. 


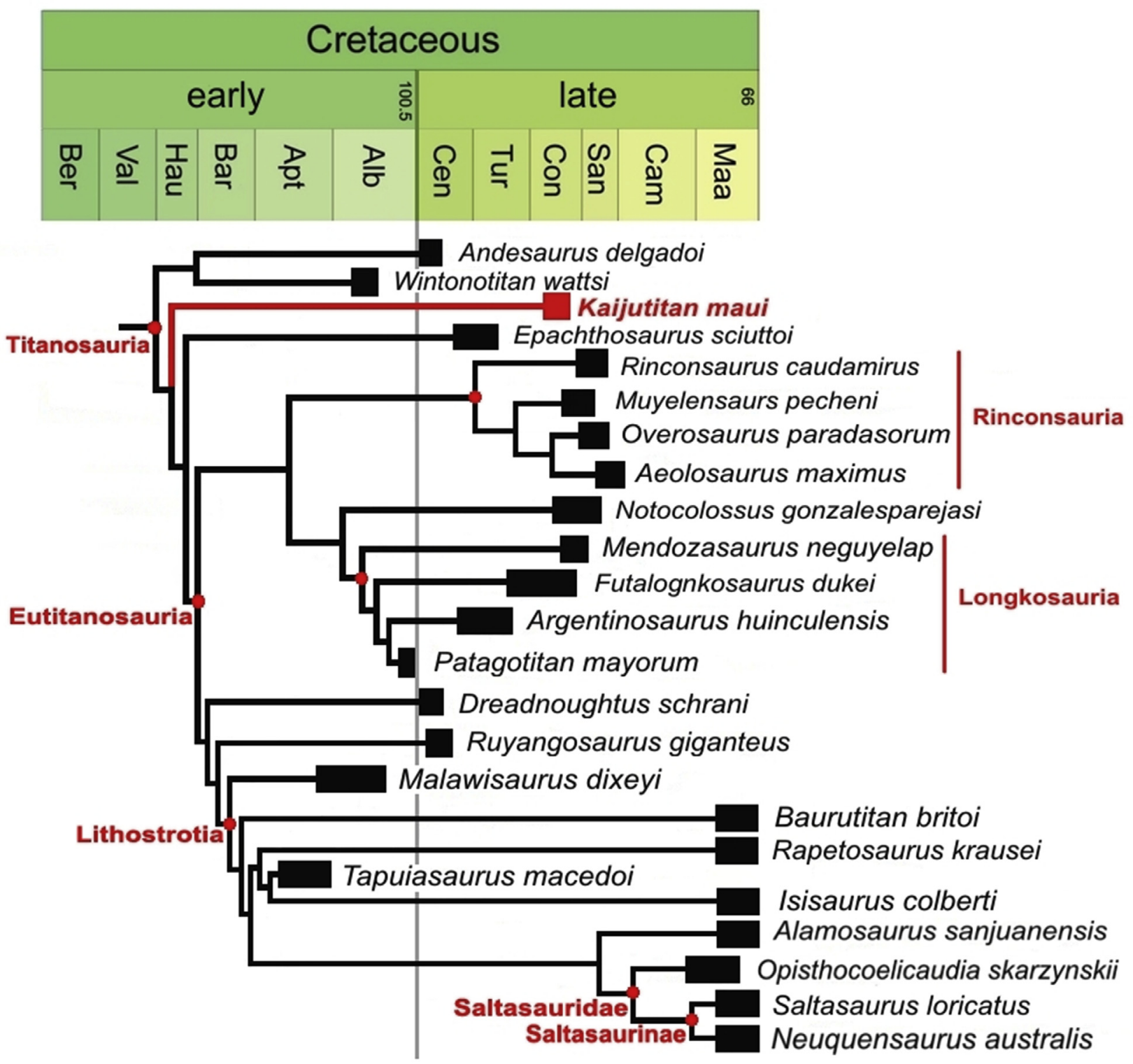

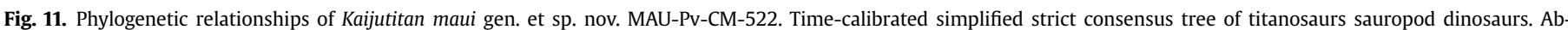

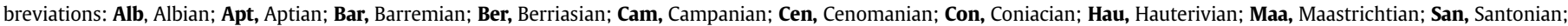
Tur, Turonian; Vlg, Valanginian. Numbers indicate millions of years ago.

Ten skeletal elements were compared: neurocranium, posterior cervical vertebrae, coracoid, sternal plate, scapula, humerus, ulna, femur, tibia and astragalus. According to the comparative measurements (see Table SI2 and SI3, Supplementary information), Kaijutitan would have had a body mass similar or intermediate to that of Giraffatitan (38.000 kg; Gunga et al., 2008) and Notocolossus (60.398 kg; González Riga et al., 2016) However, better preserved materials of the Kaijutitan are necessary to corroborate this.

\subsection{Anatomical traits}

The neurocranium of Kaijutitan present some titanosaurian features (sensu Paulina Carabajal et al., 2008), as the anteroposteriorly compressed and posteriorly oriented morphology of the crista antotica of the laterosphenoid, the complete fusion between the prootic and the exoccipital-opisthotic complex, an oval metotic foramen that is as large as the exit of cranial nerve $\mathrm{V}$, and that is visible in lateral view, and an oval fenestra that is separated from the metotic fenestra by a thin wall of bone.

The internal carotids, positioned posteriorly to the basipterygoid processes, almost at the mid-way between these and the basal tuberosities, are intermediate between the lateral location present in the primitive sauropods and the medial location present in more derived forms. In this work, this intermediate condition is considered as an autapomorphie.

Kaijutitan also presents a combination of plesiomorphic characters such as: oval sternal plate (character 293, state 0), proximodistal length of the coracoid less than the joint length scapular (character 287, state 0), non-quadrangular coracoid (character 288, state 0 ), proximal compressed condyle of tibia, narrow with anteroposterior long axis (character 363, state 0 ), and apomorphic characters such as procoelous anterior caudal vertebra (character 231, state 3), manual phalanges absent in digits II and III (character 324 , state 2) and extremely reduced fourth trochanter of femur (character 353, state 2). 
Among the most notable autapomorphies exhibited by Kaijutitan is the anterior cervical vertebra with bifid neural spine. In sauropods, bifid presacral neural spines evolved several times independently: they are present in some mamenchisaurids, all known diplodocids and dicraeosaurids, the basal macronarian Camarasaurus and Dongyangosaurus (Lü et al., 2010), in the Euhelopodidae, and in the derived titanosaur Opisthocoelicaudia (Wedel y Taylor, 2013).

The basal macronarian sauropod Camarasaurus and the diplodocoid Suuwassea emilieae (Harris and Dodson, 2004), present anterior cervical vertebrae with shallow bifurcate spines, middle cervical vertebrae with spines moderately bifurcated, and posterior cervical vertebrae with spines deeply bifurcated. In the euhelopodid Phuwiangosaurus sirindhornae (Martin et al., 1994), the middle cervicals are moderately bifurcated and posterior cervicals are deeply bifurcated. Kaijutitan is different since moderate bifurcation begins in the anterior cervical neural espines. Although the neural spine of the posterior cervical of Kaijutitan has not been preserved, it is inferred that it would have been deeply bifurcated, based on these other sauropods.

The presence of an epipophyseal-prezygapophyseal lamina in the posterior cervical vertebra of Kaijutitan is recovered in the phylogenetic analysis as an autapomorphy. This lamina is observed in many basal macronarians (e.g. Camarasaurus and Galvesaurus), rebbachisaurids (e.g. Nigersaurus, Zapalasaurus and Limaysaurus), Euhelopodidae (e.g. Erketu and Phuwiangosaurus) and in the titanosaur Patagotitan. In its most basic form, it divides the spinodiaphophyseal fossa (sdf) into upper (sdf1) and lower (sdf2) subfossae (Wilson, 2012; Fig. 6). This condition is observed in Kaijutitan, Brachiosaurus and Phuwiangosaurus (Suteethorn et al., 2009; Fig. 12).

\subsection{Evolutionary implications}

During the Early Cretaceous, diplodocoids declined globally and different titanosauriform groups became predominant in different continents: brachiosaurids in North America, euhelopodids in Asia, and titanosaurs in Gondwana and Eurasia. In the Latest Cretaceous, the only sauropods recorded throughout the world are derived titanosaurs (D'Emic, 2012). Specifically in South America, at least until the Turonian-Santonian, basal titanosaurs with amphiplatyan caudal vertebrae are recorded, such as Traukutitan (Juárez Valieri and Calvo, 2011) and the Loma de los Jotes titanosaur specimen (MAU-Pv-LJ-472; Filippi et al., 2008), with slightly procoelous caudal vertebrae in the anterior and posterior half of the tail. Kaijutitan extends the record of basal titanosaurs up to the late Conicacian. We ignore whether all these basal forms represent a single lineage or a clade; however, it is evident that the evolutionary picture of titanosaurs is more complex than previously thought.

\section{Concluding remarks}

The new giant sauropod, Kaijutitan maui gen. et sp. nov., is the latest basal titanosaur ever recorded. It presents a singular combination of plesiomorphic and apomorphic characters, among them, the presence of bifid cervical neural spines, an unusual feature among titanosaurs. Finally, Kaijutitan maui expands the scarce knowledge about the sauropod dinosaurs from the Sierra Barrosa Formation and provides new evidence of the coexistence of basal titanosaurs and eutitanosaurs sauropods in the Later Cretaceous (Turonian-Santonian) at least for Patagonia (Leanza et al., 2004; Salgado and Bonaparte, 2007).

\section{Acknowledgments}

We thank to A. Kramarz and D. Cabaza for providing measures on some of the sauropods holotypes skulls from the collection of the Museo Argentino de Ciencias Naturales "Bernardino Rivadavia” and Museo Paleontológico de Lamarque respectively, which are they are under his care; to A. Paulina-Carabajal, for the comments and suggestions that allowed to enrich part of this work, to J. L. Carballido for the discussions regarding phylogenetic aspects, especially to S. Palomo, technician of the MAU, who found the specimen, to C. Fuentes and A. Schenkel, MAU technicians, who participated in the extraction and preparation of the material and the Municipality of Rincon de los Sauces, for the logistical support provided during the fieldworks. Partial funds to L.Salgado were provided by PI UNRN 40-A-580. Finally we thank to the editor E. Koutsoukos, V. Diez Díaz and P. D. Mannion for the corrections and useful comments that improved the quality of this contribution.

\section{References}

Barrett, P.M., Benson, R.B.J., Upchurch, P., 2010. Dinosaur of Dorset: Part II, the Sauropod dinosaur (Saurischia, Sauropoda) with additional comments on the theropods. Proceedings of the Dorset Natural History and Archaeological Society $131,113-126$.

Benson, R.B.J., Campione, N.E., Carrano, M.T., Mannion, P.D., Sullivan, C., Upchurch, P., Evans, D.C., 2014. Rates of dinosaur body mass evolution indicate 170 million years of sustained ecological innovation on the avian stem lineage. PLoS Biology 12, e1001853.

Berman, D.S., Jain, S.L., 1982. The braincase of a small sauropod dinosaur (Reptilia: Saurischia) from the Upper Cretaceous Lameta Group, central India, with review of Lameta Group localities. Annals of Carnegie Museum 51, 405-422.

Bonaparte, J.F., 1986. The early radiation and phylogenetic relationships of the Jurassic sauropod dinosaurs, based on vertebral anatomy. In: Padian, K. (Ed.), The Beginning of the Age of Dinosaurs. Cambridge University Press, Cambridge, p. 247-258.

Bonaparte, J.F., Coria, R.A., 1993. Un nuevo y gigantesco saurópodo Titanosaurio de la Formación Río Limay (Albiano-Cenomaniano) de la provincia del Neuquén, Argentina. Ameghiniana 30, 271-282.

Bonaparte, J.F., Heinrich, W.D., Wild, R., 2000. Review of Janenschia Wild, with the description of a new sauropod from the Tendaguru beds of Tanzania and a discussion on the systematic value of procoelus caudal vertebra in the Sauropoda. Palaeontographica Abteilung A 256, 25-76.

Bonaparte, J.F., González Riga, B.J., Apesteguía, S., 2006. Ligabuesaurus leanzai gen. et sp. nov. (Dinosauria, Sauropoda), a new titanosaur from the Lohan Cura Formation (Aptian, Lower Cretaceous) of Neuquén, Patagonia, Argentina. Cretaceous Research 27, 364-376.

Bonaparte, J.F., Powell, J.E., 1980. A continental assemblage of tetrapods from the upper cretaceous beds of El Brete, North-western Argentina (Sauropoda-Coelurosauria-Carnosauria-Aves). Mémoires de le Société Géologique de France, N. S. $59,18-28$.

Borsuk-Bialynicka, M., 1977. A new camarasaurid sauropod Ophistocoelicaudia skarzynskii gen. n., sp. n. from de Upper Cretaceus of Mongolia. Palaeontológica Polonica 37, 5-64.

Calvo, J.O., González Riga, B., 2003. Rinconsaurus caudamirus gen. et sp. nov., a new titanosaurid (Dinosauria, Saurópoda) from the late Cretaceous of Patagonia, Argentina. Revista Geologica de Chile 30 (2), 333-353.

Calvo, J.O., Kellner, A.W., 2006. Description of a sauropod dinosaur braincase (Titanosauridae) from the Late Cretaceous Rio Colorado Subgroup, Patagonia. Anais da Academia Brasileira de Ciencias 78, 175-182.

Calvo, J.O., Porfiri, J.D., González Riga, B.J., Kellner, A.W.A., 2007a. A new Cretaceous terrestrial ecosystem from Gondwana with the description of a new sauropod dinosaur. Anais da Academia Brasileira de Ciências 79 (3), 1-13.

Calvo, J.O., González Riga, B.J., Porfiri, J.A., 2007b. A new titanosaur sauropod from the Late Cretaceous of Neuquén, Patagonia, Argentina. Arquivos do Museu Nacional 65, 485-504.

Calvo, J.O., Porfiri, J.D., González Riga, B.J., Kellner, A.W.A., 2007c. Anatomy of Futalognkosaurus dukei Calvo, Porfiri, González Riga \& Kellner, 2007 (Dinosauria, Titanosauridae) from the Neuquén Group (Late Cretaceous), Patagonia, Argentina. Arquivos do Museu Nacional, Rio de Janeiro 65 (4), 511-526.

Campos, D.A., Kellner, A.W.A., Bertini, R.J., Santucci, R.M., 2005. On a titanosaurid (Dinosauria, Sauropoda) vertebral column from the Baru group, Late Cretaceous of Brazil. Arquivos do Museu Nacional, Rio de Janeiro 63, 565-593.

Campione, N.E., Evans, D.C., 2012. A universal scaling relationship between body mass and proximal limb bone dimensions in quadrupedal terrestrial tetrapods. BMC Biology 10, 60. https://doi.org/10.1186/1741-7007-10-60.

Carballido, J.L., Pol, D., Cerda, I., Salgado, L., 2011. The osteology of Chubutisaurus insignis Del Corro, 1975 (Dinosauria: Neosauropoda) from the 'Middle' Cretaceous of central Patagonia, Argentina. Journal of Vertebrate Paleontology 31 (1), 93- 110 .

Carballido, J.L., Pol, D., Otero, A., Cerda, I.A., Salgado, L., Garrido, A.C., Ramezzani, J., Cúneo, N.R., Krause, M.J., 2017. A new giant titanosaur sheds light on body mass evolution among sauropod dinosaurs. Proceedings of the Royal Society Series B, 20171219. https://doi.org/10.1098/rspb.2017.1219. 
Cerda, I., Paulina Carabajal, A., Salgado, L., Coria, R.A., Reguero, M.A., Tambussi, C.P., Moly, J.J., 2012. The first record of a sauropod dinosaur from Antarctica. Naturwissenschaften 99 (1), 83-87.

Chatterjee, S., Zheng, Z., 2002. Cranial anatomy of Shunosaurus, a basal sauropod dinosaur the Jurassic of China. Zoological Journal of the Linnean Society 136, 145-169.

Chatterjee, S., Zheng, Z., 2005. Neuroanatomy and dentition of Camarasaurus lentus. In: Tidwell, V., Carpenter, K. (Eds.), Thunder-lizards: The Sauropodomorph dinosaur. Indiana University Press, Bloomington, pp. 199-211.

Coria, R.A., Filippi, L.S., Chiappe, L.M., García, R.A., Arcucci, A.B., 2013. Overosaurus paradasorum gen. et sp. nov., a new sauropod dinosaur (Titanosauria: Lithostrotia) from the Late Cretaceous of Neuquén, Patagonia, Argentina. Zootaxa 3683, 357-376.

Curry-Rogers, K., Forster, C.A., 2004. The skull of Rapetosaurus krausei (Sauropoda: Titanosauria) from the Late Cretaceous of Madagascar. Journal of Vertebrate Paleontology 24, 121-144.

Curry Rogers, K.A., 2009. The postcranial osteology of Rapetosaurus krausei (Sauropoda: Titanosauria) from the Late Cretaceous of Madagascar. Journal of Vertebrate Paleontology 29, 1046-1086.

Curry Rogers, K., Wilson, J.A., 2014. Vahiny depereti, gen. et sp. nov., a new titanosaur (Dinosauria, Sauropoda) from the Upper Cretaceous Maevarano Formation, Madagascar. Journal of Vertebrate Paleontology 34 (3), 606-617.

D'Emic, M.D., 2012. The early evolution of titanosauriform sauropod dinosaurs. Zoological Journal of the Linnean Society 166, 624-671.

D'Emic, M.D., 2013. Revision of the sauropod dinosaurs of the Lower Cretaceous Trinity Group, southern USA, with the description of a new genus. Journal of Systematic Palaeontology 11 (6), 707-726.

D'Emic, M.D., Wilson, J.A., Williamson, T.E., 2011. A Sauropod Dinosaur Pes from the Latest Cretaceous of North America and the Validity of Alamosaurus sanjuanensis Sauropoda Titanosauria. Journal of Vertebrate Paleontology 31 (5), 1072-1079.

D'Emic, M.D., Mannion, P.D., Upchurch, P., Benson, R.B.J., Pang, Q., Zhengwu, C., 2013. Osteology of Huabeisaurus allocotus (Sauropoda: Titanosauriformes) from the Upper Cretaceous of China. PLoS One 8 (8), e69375. https://doi.org/10.1371/ journal.pone.0069375.

del Corro, G., 1975. Un nuevo saurópodo del Cretácico Chubutisaurus insignis gen. et sp. nov. (Saurischia-Chubutisauridae nov.) del Cretácico Superior (Chubutiano), Chubut,Argentina, 12-16 August 1974. Actas I Congreso Argentino de Paleontología y Bioestratigrafía, Tucuman 2, 229-240.

Díez Díaz, V., Pereda Suberbiola, X., Sanz, J.L., 2011. Braincase anatomy of the sauropod dinosaur Lirainosaurus astibiae (Titanosauria) from the Late Cretaceous of the Iberian Peninsula. Acta Paleontologica Polonica 56, $521-533$.

Filippi, L.S., Garrido, A.C., 2008. Pitekunsaurus macayai gen. et sp. nov., nuevo titanosaurio (Saurischia, Sauropoda) del Cretácico Superior de la Cuenca Neuquina, Argentina. Ameghiniana 45, 575-590.

Filippi, L.S., Canudo, J.I., Salgado, L., Garrido, A., Cerda, I., Otero, A., Fernández, M., y Gallina, P., 2008. Un titanosaurio (Saurischia, Sauropoda) con caudales medias anfipláticas, proveniente de la Formación Plottier (Cretácico Superior) Norpatagonia, Argentina. Reunión Anual de Comunicaciones de la Asociación Paleontológica Argentina. Ameghiniana 45 (4), 27. Suplemento Resúmenes.

Filippi, L.S., Canudo, J.I., Salgado, L., Garrido, A.C., García, R.A., Cerda, I.A., Otero, A., 2011a. A new sauropod titanosaur from the Plottier Formation (Upper Cretaceous) of Patagonia (Argentina). Geologica Acta 9, 1-12.

Filippi, L.S., García, R.A., Garrido, A., 2011b. A new titanosaur sauropod dinosaur from Upper Cretaceous of North Patagonia, Argentina. Acta Palaeontologica Polonica 56, 505-520.

Filippi, L.S., Martinelli, A.G., Garrido, A.C., 2013. Registro de un dinosaurio Aeolosaurini (Sauropoda, Titanosauria) en el Cretácico Superior (Formación Plottier) del Norte de la Provincia de Neuquén, Argentina, y comentarios sobre los Aeolosaurini sudamericanos. Revista Brasilera de Paleontología 16 (1), 147-156.

Gallina, P.A., Apesteguía, S., 2015. Postcranial anatomy of Bonitasaura salgadoi (Sauropoda, Titanosauria) from the Late Cretaceous of Patagonia. Journal of Vertebrate Paleontology 35. https://doi.org/10.1080/02724634.2014. 924957.

García, R., Paulina-Carabajal, A., Salgado, L., 2008. Un nuevo basicráneo de titanosaurio de la Formación Allen (Campaniano-Maastrichtiano), Provincia de Río Negro, Patagonia, Argentina. Geobios 41 (5), 625-633.

Gilmore, C.W., 1922. A new sauropod dinosaur from the Ojo Alamo Formation of New Mexico. Smithsonian Miscellaneous Collections 72, 1-9.

Gilmore, C.W., 1933. Two new dinosaurian reptiles from Mongolia with notes on some fragmentary specimens. American Museum Novitates 679, 1-20.

Gilmore, C.W., 1946. Reptilian fauna from the North Horn Formation of central Utah, vol. 210. United States Geological Survey Professional Paper, pp. 29-52.

Goloboff, P.A., Catalano, S.A., 2016. TNT version 1.5, including a full implementation of phylogenetic morpho-metrics. Cladistics 32 (3), 221-238. https://doi.org/ 10.1111/cla.12160.

Gomani, E.M., 2005. Sauropod dinosaur from the Early Cretaceous Malawi, Africa. Paleontologia Electronica 8, 1-37.

González Riga, B.J., 2003. A new titanosaur (Dinosauria, Sauropoda) from the Upper Cretaceous of Mendoza Province, Argentina. Ameghiniana 40 (2), 155-172.

González Riga, B.J., 2005. Nuevos restos fósiles de Mendozasaurus neguyelap (Sauropoda: Titanosauridae) del Cretácico Tardío de Mendoza, Argentina. Ameghiniana 42, 535-538.
González Riga, B.J., Calvo, J.O., Porfiri, J., 2008. An articulated titanosaur from Patagonia (Argentina): new evidence of neosauropod pedal evolution. Palaeoworld 17, 33-40.

González Riga, B.J., Lamanna, M.C., Ortiz David, L.D., Calvo, J.O., Coria, J.P., 2016 A gigantic new dinosaur from Argentina and the evolution of the sauropod hind foot. Nature 6, 19165

González Riga, B.J., Mannion, P.D., Poropar, S.F., Ortiz David, L., Coria, J.P., 2018. Osteology of the Late Cretaceous Argentinean sauropod dinosaur Mendozasaurus neguyelap: implications for basal titanosaur relationships. Zoological Journal of the Linnean Society. https://doi.org/10.1093/ zoolinnean/zlx103.

Gunga, H.-C., Suthau, T., Bellmann, A., Stoinski, S., Friedrich, A., Trippel, T., Kirsch, K., Hellwich, O., 2008. A new body mass estimation of Brachiosaurus brancai Janensch, 1914 mounted and exhibited at the Museum of Natural History (Berlin, Germany). Museum f ür naturkunde der Humboldt-Universität zu Berlin. Fossil Record 11 (1), 33-38.

Harris, J.D., Dodson, P., 2004. A new diplodocoid sauropod dinosaur from the Upper Jurassic Morrison Formation of Montana, USA. Acta Palaeontologica Polonica 49 (2), 197-210.

Harris, J.D., 2006. The axial skeleton of Suuwassea emilieae (Sauropoda: Flagellicaudata) from the Upper Jurassic Morrison Formation of Montana, USA. Palaeontology 49, 1091-1121.

Holland, W.J., 1906. The osteology of Diplodocus Marsh, with special reference to the restoration of the skeleton of Diplodocus carnegiei Hatcher. Memoirs of the Carnegie Museum 2, 225-264.

Huene, F., 1929. Los saurisquios y ornitisquios del Cretácico Argentino. Anales del Museo de La Plata 3, 1-196.

Jacobs, L.L., Winkler, D.A., Downs, W.R., Gomani, E.M., 1993. New material of an early Cretaceous Titanosaurid Sauropod dinosaur from Malawi. Palaeontology 36, 523-534.

Janensch, W., 1914. Ubersichtu ber der Wirbeltierfauna der Tendaguru- Schichten nebst einer kurzen Charakterisierung der neu aufgefuhrten Arten von Sauropoden. Archiv für Biontologie 3, 81-110.

Janensch, W., 1935. Die Schadel der Sauropoden Brachiosaurus, Barosaurus und Dicraeosaurus aus den Tendaguru-Schichten Deutsch-Ostafrikas. Palaeontographica 2 (Suppl. 7), 147-298.

Juárez Valieri, R.D., Calvo, J.O., 2011. Revision of MUCPv 204, a Senonian basal titanosaur from northern Patagonia. In: Paleontologia y dinosaurios desde América Latina (Calvo, Porfiri, González Riga y Dos Santos, editores). Editorial de la Universidad Nacional de Cuyo, pp. 143-152.

Kellner, A.W.A., Campos, D.A., Trotta, M.N.F. 2005. Description of a titanosauric caudal series from the Bauru Group, Late Cretaceous of Brazil. Arquivos do Museu Nacional 63 (3), 529-564.

Ksepka, D.T., Norell, M.A., 2006. Erketu ellisoni, a long-necked sauropod from Bor Guvé (Dornogov Aimag, Mongolia). American Museum Novitates 3508, 1-16.

Kurzanov, S.M., Bannikov, A.F., 1983. A new sauropod from the Upper Cretaceous of Mongolia [in Russian with English translation]. Paleontologičeskij žurnal 1983 (2), 90-97.

Lacovara, K.J., Lamanna, M.C., Ibiricu, L.M., Poole, J.C., Schroeter, E.R., Ullmann, P.V. Voegele, K.K., Boles, Z.M., Carter, A.M., Fowler, E.K., Egerton, V.M., Moyer, A.E. Coughenour, C.L., Schein, J.P., Harris, J.D., Martínez, R.D., Novas, F.E., 2014. Gigantic, exceptionally complete titanosaurian sauropod dinosaur from southern Patagonia, Argentina. Scientific Reports 4, 6196.

Leanza, H.A., Apesteguía, S., Novas, F.E., De la Fuente, M.S., 2004. Cretaceous terrestrial beds from the Neuquén basin (Argentina) and their tetrapod assemblages. Cretaceous Research 25, 1-96.

Lehman, T.M., Coulson, A.B., 2002. A juvenile specimen of the sauropod dinosaur Alamosaurus sanjuanensis from the Upper Cretaceous of Big Bend National Park, Texas. Journal of Vertebrate Paleontology 76, 156-172.

Li, L.G., Li, D.Q., You, H.L., Dodson, P., 2014. A New Titanosaurian Sauropod from the Hekou Group (Lower Cretaceous) of the Lanzhou-Minhe Basin, Gansu Province, China. En Butler, Richard J. PLoS One 9, e85979.

Lu, J., Xu, J., Jia, S., Zhang, X., Zhang, J., Yang, L., You, H., Ji, Q., 2009. A new gigantic sauropod dinosaur from the Cretaceous of Ruyang, Henan, China. Geological Bulletin of China 28, 1-10.

Lydekker, R., 1893. The dinosaurs of Patagonia. Anales del Museo de la Plata. Sección de Paleontología 2, 1-14.

Mannion, P.D., 2011. A reassessment of Mongolosaurus haplodon Gilmore, 1933, a titanosaurian sauropod dinosaur from the Early Cretaceous of Inner Mongolia, People's Republic of China. Journal of Systematic Palaeontology 9, 355-378.

Mannion, P.D., Otero, A., 2012. A reappraisal of the Late Cretaceous Argentinean sauropod dinosaur Argyrosaurus superbus, with a description of a new titanosaur genus. Journal of Vertebrate Paleontology 32 (3), 614-638.

Mannion, P.D., Upchurch, P., Barnes, R.N., Mateus, O., 2013. Osteology of the Late Jurassic Portuguese sauropod dinosaur Lusotitan atalaiensis (Macronaria) and the evolutionary history of basal titanosauriforms. Zoological Journal of the Linnean Society 168, 98-206.

Marpmann, J.S., Carballido, J.L., Martin Sander, P., Knötschke, N., 2014. Cranial anatomy of the Late Jurassic dwarf sauropod Europasaurus holgeri (Dinosauria, Camarasauromorpha): ontogenetic changes and size dimorphism, Journal of Systematic Palaeontology. Journal of Systematic Palaeontology 13, 221-263.

Martinelli, A.G., Forasiepi, A.M., 2004. Late Cretaceous vertebrates from Bajo de Santa Rosa (Allen Formation), Río Negro province, Argentina, with the 
description of a new sauropod dinosaur (Titanosauridae). Revista Museo Argentino de Ciencias Naturales, Nueva Serie 6, 257-305.

Mateus, O., Mannion, P.D., Upchurch, P., 2014. Zby atlanticus, a new turiasaurian sauropod (Dinosauria, Eusauropoda) from the Late Jurassic of Portugal. Journa of Vertebrate Paleontology 34 (3), 618-634.

Nowiński, A., 1971. Nemegtosaurus mongoliensis nov. gen., nov. sp. (Sauropoda) from the uppermost Cretaceous of Mongolia. Palaeontologia Polonica 25, $57-81$.

Otero, A., 2010. The appendicular skeleton of Neuquensaurus, a Late Cretaceous saltasaurine sauropod from Patagonia, Argentina. Acta Palaeontologica Polonica 55 (3), 399-426.

Otero, A., 2018. Forelimb musculature and osteological correlates in Sauropodomorpha (Dinosauria, Saurischia). PLoS One 13 (7), e0198988. https:/ doi.org/10.1371/journal.pone.0198988.

Paul, G.S., 1988. The brachiosaur giants of the Morrison and Tendaguru with a description of a new subgenus, Giraffatitan, and a comparison of the world's largest dinosaurs. Hunteria 2, 1-14.

Paulina Carabajal, A., 2012. Neuroanatomy of titanosaurid dinosaurs from the Upper Cretaceous of Patagonia, with comments on endocranial variability within Sauropoda. Anatomical Record 295, 2141-2156.

Paulina Carabajal, A., Salgado, L., 2007. El basicráneo de un titanosaurio (Dinosauria, Sauropoda) del Cretácico Superior del norte de Patagonia: descripción y aportes al conocimiento del oído interno de los dinosaurios. Ameghiniana 44, 109-120.

Paulina Carabajal, A., Carballido, J.L., Currie, P.H., 2014. Braincase, neuroanatomy and neck posture of Amargasaurus cazaui (Sauropoda, Dicraeosauridae) and its implications for understanding head posture in sauropods. Journal of Vertebrate Paleontology 34 (4), 870-882.

Paulina Carabajal, A., Coria, R.A., Chiappe, L.M., 2008. An incomplete Late Cretaceous braincase (Sauropoda: Titanosauria): new insights about the dinosaurian inner ear and endocranium. Cretaceous Research 29, 643-648.

Poropat, S.F., Mannion, P.D., Upchurch, P., Hocknull, S.A., Kear, B.P., Elliott, D.A., 2014 Reassessment of the Non-Titanosaurian Somphospondylan Wintonotitan watts (Dinosauria: Sauropoda: Titanosauriformes) from the Mid-Cretaceous Winton Formation, Queensland, Australia. Palaeontology 1-48.

Poropat, S.F., Upchurch, P., Mannion, P.D., Hocknull, S.A., Kear, B.P., Sloan, T., Sinapius, G.H.K., Elliott, D.A., 2015. Revision of the sauropod dinosaur Diamantinasaurus matildae Hocknull et al. 2009 from the middle Cretaceous of Australia: implications for Gondwanan titanosauriform dispersal. Gondwana Research 27, 995-1033.

Poropat, S.F., Mannion, P.D., Upchurch, P., Hocknull, S.A., Kear, B.P., Kundrát, M., Tischler, T.R., Sloan, T., Sinapius, G.H.K., Elliott, J.A., Elliott, D.A., 2016. New Australian sauropods shed light on Cretaceous dinosaur palaeobiogeography. Nature, Scientific Reports 6, 34467.

Powell, J.E., 1987. The Late Cretaceous Fauna from Los Alamitos, Patagonia, Argentina. Part. VI. The titanosaurids. Revista Museo Argentino Ciencias Naturales 3 (3), 147-153.

Powell, J.E. 1992. Osteología de Saltasaurus loricatus (Saurópoda-Titanosauridae) del Cretácico Superior del Noroeste argentino. In: Sanz, J.L., Buscalioni, y A.D. (Eds.), Los Dinosaurios y su entorno Biótico. Insituto "Juan de Valdes", Cuenca, pp. 165-230.

Powell, J.E., 2003. Revision of South American Titanosaurid dinosaurs: palaeobiological, palaeobiogeographical and phylogenetic aspects. Records of the Queen Victoria Museum Launceston 1-173.

Rose, P.J., 2007. A titanosauriform (Dinosauria: Saurischia) from the Early Cretaceous of Central Texas and its phylogenetic relationships. Palaeontologica Electronica 10, 1-65.

Royo-Torres, R. Upchurch, P. 2012. The cranial anatomy of the sauropod Turiasaurus riodevensis and implications forits phylogenetic relationships. Journal of Systematic Palaeontology 10, 553-583.

Salgado, L., Bonaparte, J.F., 1991. Un nuevo sauropod Dicraeosauridae, Amargasaurus cazaui gen. et sp. nov de la Formación La Amarga, Neocomiano de la Provincia del Neuquén, Argentina. Ameghiniana 28, 333-346.

Salgado, L., Bonaparte, J.F., 2007. Sauropodomorpha. In: Gasparini, Z., Salgado, L. Coria, R.A. (Eds.), Patagonian Mesozoic reptiles. Indiana University Press, Bloomington, pp. 188-228.

Salgado, L., Calvo, J.O., 1992. Cranial osteology of Amargasaurus cazaui Salgado \& Bonaparte (Sauropoda, Dicraeosauridae) from the Neocomian of Patagonia. Ameghiniana 29, 337-346.

Salgado, L., Calvo, J.O., 1997. Evolution of titanosaurid sauropods. II: the crania evidence. Ameghiniana 34, 33-48.

Salgado, L., Coria, R., Calvo, J.O., 1997. Presencia del genero Aeolosaurus (Sauropoda, Titanosauridae) en la Formación Los Alamitos, Cretácico Superior de la provincia de Río Negro, Argentina. Geociências 2 (6), 44-46.

Salgado, L., Carvalho, I.S., 2008. Uberabatitan ribeiroi, a new titanosaur from the Marília Formation (Bauru Group, Upper Cretaceous), Minas Gerais, Brazil. Palaeontology 51 (4), 881-901.

Sander, P.M., Christian, A., Clauss, M., Fechner, R., Gee, C.T., Griebeler, E.M. Gunga, H.C., Hummel, J., Mallison, H., Perry, S.F., Preuschof, T.H., Rauhut, O.W.M.,
Remes, K., Tütken, T., Wings, O., Witzel, U., 2011. Biology of the sauropod dinosaurs: the evolution of gigantism. Biological Reviews of the Cambridge Philosophical Society 86, 117-155.

Schwarz, D., Frey, E., Meyer, C.A., 2007. Pneumaticity and soft-tissue reconstructions in the neck of diplodocid and dicraeosaurid sauropods. Acta Palaeontologica Polonica 52 (1), 167-188.

Suteethorn, S., Le Loeuff, J., Buffetaut, E., Suteethorn, V., Talubmook, C., Chonglakmani, C., 2009. A new skeleton of Phuwiangosaurus sirindhornae (Dinosauria, Sauropoda) from NE Thailand. The Geological Society, London, Special Publications 315, 189-215.

Tschopp, et al., 2015. A specimen-level phylogenetic analysis and taxonomic revision of Diplodocidae (Dinosauria, Sauropoda). PeerJ 3, e857. https://doi.org/ 10.7717 /peerj.857.

Tsuihiji, T., 2004. The ligament system in the neck of Rhea americana and ist implications for the bifurcated neural spines of sauropod dinosaurs. Journal of Vertebrate Paleontology 24, 165-172.

Upchurch, P., 1995. The evolutionary history of sauropod dinosaurs. Philosophical Transactions of the Royal Society of London, Series B 349, 365-390.

Upchurch, P., 1998. The phylogenetic relationships of sauropod dinosaurs. Zoological Journal of the Linnean Society 124, 43-103.

Upchurch, P., Barrett, P.M., Dodson, P., 2004. Sauropoda. In: Weishampel, D.B., Dodson, P., Osmólska, H. (Eds.), The Dinosauria, segunda edición. University of California Press, Berkley, pp. 259-322.

Wedel, M.J., Cifelli, R.L., Sanders, R.K., 2000. Sauroposeidon proteles, a new sauropod from the Early Cretaceous of Oklahoma. Journal of Vertebrate Paleontology 20, 109-114.

Wedel, M.J., Taylor, M.P., 2013. Neural Spine Bifurcation in Sauropod Dinosaurs of the Morrison Formation: Ontogenetic and Phylogenetic Implications. Palarch's Journal of Vertebrate Palaeontology 10 (1), 1-34.

Wilson, J.A., 2002. Sauropod dinosaur phylogeny: critique and cladistic analysis. Zoological Journal of the Linnean Society 136, 217-276.

Wilson, J.A., 2005. Redescription of the Mongolian Sauropod Nemegtosaurus mongoliensis Nowinski (Dinosauria: Saurischia) and comments on Late Cretaceous Sauropod diversity. Journal of Systematic Palaeontology 3 (3), 283-318.

Wilson, J.A., Curry Rogers, K., 2005. Monoliths of the Mesozoic. In: Curry Rogers, K., Wilson, J.A. (Eds.), The sauropods: evolution and paleobiology. University of California Press, Berkeley, pp. 1-40.

Wilson, J.A., Sadiq Malkani, M., Gingerich, P.D., 2005. A Sauropod braincase from the Pab Formation (Upper Cretaceous, Maastrichtian) of Balochistan, Pakistan. Gondwana Geological Magazine 8, 101-109.

Wilson, J.A., Sereno, P.C., 1998. Early evolution and higher-level phylogeny of sauropod dinosaurs. Society of Vertebrate Paleontolology Memoir 5, 1-68.

Wilson, J.A., Upchurch, P., 2009. Redescription and reassessment of the phylogenetic affinities of Euhelopus zdanskyi (Dinosauria: Sauropoda) from the Late Jurassic or Early Cretaceous of China. Journal of Systematic Palaeontology 7, 199-239.

Wilson, J.A., D'Emic, M.D., Curry Rogers, K., Mohabey, D.M., Sen, S., 2009. Reassessment of the sauropod dinosaur Jainosaurus (="Antarctosaurus") septentrionalis from the Upper Cretaceous of India. Contributions from the University of Michigan Museum of Paleontology 32, 17-40.

Wilson, J.A., Barrett, P.M., Carrano, M.T., 2011a. An associated partial skeleton of Jainosaurus cf. septentrionalis (Dinosauria: Sauropoda) from the Late Cretaceous of Chhota Simla, central India. Palaeontology 54, 981-998.

Wilson, J.A., D'Emic, M.D., Ikejiri, T. Moacdieh, E.M., Whitlock, J.A., 2011b. A nomenclature for vertebral fossae in sauropods and other saurischian dinosaurs. PLoS One 6, e17114.

Wilson, J.A., 2012. New vertebral laminae and Patterns of Serial Variation in Vertebral Laminae of Sauropod Dinosaurs. Contributions Museum of Paleontology, University of Michigan 32 (7), 91-110.

Wilson, J.A., Pol, D., Carvalho, A.B., Zaher, H., 2016. The skull of the titanosaur Tapuiasaurus macedoi (Dinosauria: Sauropoda), a basal titanosaur from the Lower Cretaceous of Brazil. Zoological Journal of the Linnean Society 178 (3), $611-662$.

Yates, A.M., 2007. Solving a dinosaurian puzzle: the identity of Aliwalia rex Galton. Historical Biology 19 (1), 93-123.

You, H., Tang, F., Luo, Z., 2003. A new basal titanosaur (Dinosauria: Sauropoda) from the Early Cretaceous of China. Acta Geologica Sinica 77, 424-429.

Zaher, H., Pol, D., Carvalho, A.B., Nascimento, P.M., Roccomini, C., Larson, P., JuarezValieri, R.D., Pires-Domingues, R., da Silva, N.J., Campos, D.A., 2011. A complete skull of an Early Cretaceous sauropod and the evolution of advanced titanosaurians. PLoS One 6, e16663.

\section{Appendix A. Supplementary data}

Supplementary data to this article can be found online at https://doi.org/10. 1016/j.cretres.2019.03.008. 